NBER WORKING PAPER SERIES

\title{
TEMPORARY SHOCKS AND PERSISTENT EFFECTS IN THE URBAN SYSTEM: EVIDENCE FROM BRITISH CITIES AFTER THE U.S. CIVIL WAR
}

\author{
W. Walker Hanlon \\ Working Paper 20471 \\ http://www.nber.org/papers/w20471 \\ NATIONAL BUREAU OF ECONOMIC RESEARCH \\ 1050 Massachusetts Avenue \\ Cambridge, MA 02138 \\ September 2014
}

For their helpful comments and suggestions I thank Jeremy Atack, Leah Boustan, Ryan Chahrour, Don Davis, Ronald Findlay, Richard Hornbeck, William Kerr, Amit Khandelwal, Tim Leunig, Guy Michaels, Matthew Notowidigdo, Henry Overman, Humphrey Southall, Eric Verhoogen, Jonathan Vogel, David Weinstein, Jeffrey Williamson and seminar participants at Caltech, Vanderbilt, Columbia and UCLA. Thanks to Matthew Wollard and Ole Wiedenmann at the UK Data Archive for help with the data. Funding was provided by the NSF (grant no. 0962545), the Economic History Association, the Ewing Marion Kauffman Foundation, and the European Commission's Marie Currie Initial Training Network (AMID Fellowship). The views expressed herein are those of the author and do not necessarily reflect the views of the National Bureau of Economic Research.

NBER working papers are circulated for discussion and comment purposes. They have not been peerreviewed or been subject to the review by the NBER Board of Directors that accompanies official NBER publications.

(C) 2014 by W. Walker Hanlon. All rights reserved. Short sections of text, not to exceed two paragraphs, may be quoted without explicit permission provided that full credit, including $\bigcirc$ notice, is given to the source. 
Temporary Shocks and Persistent Effects in the Urban System: Evidence from British Cities after the U.S. Civil War

W. Walker Hanlon

NBER Working Paper No. 20471

September 2014

JEL No. F14,N63,N93,R12

\begin{abstract}
Urban economies are often heavily reliant on a small number of dominant industries, leaving them vulnerable to negative industry-specific shocks. This paper analyzes the long-run impacts of one such event: the large, temporary, and industry-specific shock to the British cotton textile industry caused by the U.S. Civil War (1861-1865), which dramatically reduced supplies of raw cotton. Because the British cotton textile industry was heavily concentrated in towns in Northwest England, I compare patterns in these cotton towns to other English cities. I find that the shock had a persistent negative effect on the level of city population lasting at least 35 years with no sign of diminishing. Decomposing the effect by industry, I show that the shock to cotton textiles was transmitted to other local firms, leading to increased bankruptcies and long-run reductions in employment. This transmission occurred primarily through the link to capital suppliers, such as machinery and metal-goods producers. Roughly half of the reduction in city-level employment growth was due to the impact on industries other than cotton textiles.
\end{abstract}

W. Walker Hanlon

Department of Economics University of California, Los Angeles

8283 Bunche Hall

Los Angeles, CA 90095

and NBER

whanlon@econ.ucla.edu 


\section{Introduction}

Whether it is automobile manufacturers in Detroit, technology firms in Silicon Valley, or cotton textile producers in 19th century Manchester, many cities and regions are characterized by specialization in just one or two dominant industries. One consequence of this concentrated production is that these areas may be strongly affected by temporary industry-specific volatility. When the dominant industry in a city receives a large temporary negative shock, the impact on the local economy is often clearly visible and widely discussed. But what are the long-run consequences of severe industry-specific shocks to city economies? Existing empirical work by Davis \& Weinstein (2002) shows that cities can rebound from even very large shocks. At the industry level, theoretical work suggests that temporary shocks may have "cleansing" effects that eliminate less productive units (Caballero \& Hammour (1994)), which may allow for more rapid growth in the post-shock period. These results suggest that the long-run impacts may be limited. On the other hand, recent theoretical work shows how a shock to one sector of a local economy may spread to other sectors and generate aggregate effects, if that sector is large (Gabaix (2011)) or well-connected to suppliers Acemoglu et al. (2012)). These concerns have motivated substantial government interventions aimed at cushioning the impact of industry-specific shocks to local economies 1

This study takes advantage of a unique historical event in order to provide new evidence on the long-run impact of a large industry-specific shock on city economies. The experiment is provided by the large exogenous shock to the British cotton textile industry generated by the U.S. Civil War (1861-1865). The cotton textile industry was Britain's largest manufacturing sector during the 19th century and was entirely reliant on imported supplies of raw cotton, most of which came from the U.S. South. The Civil War sharply disrupted these supplies, leading to a deep depression in the industry that saw hundreds of thousands of operatives put out of work or working short-time. Moreover, the U.S. Civil War had little direct effect on industries outside of the cotton textile industry. Thus, this event provides a large, clearly identified, temporary, and sector-specific shock.

One feature of this empirical setting is that the policy response to this event was limited, despite the fact that hundreds of thousands of workers became unemployed $2^{2}$ This lack of response was due to the strong free-market ideology that dominated British policy during this period, as well as the small size of central government. Thus, we are able to observe the impact of the shock in the absence of substantial intervention. In contrast, modern shocks

\footnotetext{
${ }^{1}$ One recent example is the billions of dollars in government loans made to automotive manufacturers in 2009 , which was aimed in part at protecting the economy of the Detroit region.

${ }^{2}$ The main government response came in the form of relief for truly destitute unemployed workers and some government-sponsored public works projects.
} 
of this magnitude are likely to elicit substantial government responses.

Another important feature of this empirical setting is that prior to the Civil War there was substantial variation across British cities in the share of employment in the cotton textile industry. Most of Britain's cotton textile employment was concentrated in towns in the Northwest region, and within these towns the cotton textile industry often provided 20$30 \%$ of employment. These initial agglomeration patterns, which date to the 18th century, were driven by historical features, such as the availability of water power, that had little direct effect on the industry by 1850 (Crafts \& Wolf (2013)). However, as a consequence of this pattern there was substantial geographic variation in the impact of the cotton shortage. This means that I am able to compare outcomes in the affected cotton textile towns to those in other British cities, where the direct impact of the U.S. Civil War was very small.

To further strengthen the analysis, I compare the cotton textile towns to a set of other British cities with economies that were heavily reliant on textile production, but based on wool, linen, or silk, rather than cotton. These other textile sectors, particularly wool textiles, were also important British industries during this period. They were also very similar to cotton textiles in terms of technologies, other inputs, and organization. However, they were not negatively impacted by the cotton shortage $3^{3}$

In the first part of the analysis, I draw on new data describing the population of British cities from 1841-1901 to show that the cotton textile towns - those with more than $10 \%$ of workers in the cotton textile sector prior to the war - suffered a reduction in decadal population growth on the order of 7-13 percentage points over the 1861-1871 period, relative to other towns in Britain. This is around half of the average decadal growth of 20-22 percent experienced in the cotton towns over the two decades prior to the war. After 1871, the growth rate returned to, but not above, normal levels. Thus, the Civil War had a temporary growth effect and a permanent levels effect on overall population in the cotton textile towns. This result holds whether I compare the cotton towns to all other British cities, or only to other textile-producing cities. The levels effect persists at least through 1901, with no sign of diminishing.

This finding contributes to the literature on persistence in urban economies ( Weinstein, 2002, 2008; Miguel \& Roland, 2011; Redding et al., 2011; Bleakley \& Lin, 2012; Kline \& Moretti, 2013)). An important difference between this paper and previous work in this area is that this paper is the first in the literature to analyze the impact of a large idiosyncratic economic shock to an important local industry. This is exactly the kind of shock

\footnotetext{
${ }^{3}$ If anything, the non-cotton textile industries show modest positive effects during the Civil War period due to the lack of competition from cotton textile products.
} 
that urban economies are periodically exposed to, and that policymakers must regularly address.

The second part of the analysis seeks to understand the mechanisms behind these effects by analyzing how each industry in the economy was impacted. I find that the shock to the cotton textile industry had both contemporaneous and long-run effects on other industries in the cotton textile towns. The most important of these was the Metal \& Machinery sector, an important sector of the economy and a key supplier of capital inputs to the cotton textile industry. I show that the shock to cotton textile producers generated an increase in bankruptcies among metal \& machinery firms during the Civil War period and had long-run negative impacts on employment in this sector in the cotton textile towns. To my knowledge, this is the first study to provide well-identified evidence that a temporary industry-specific shock, working through inter-industry connections, can generate long-lasting effects.

To generate these results, I draw on two new sets of data. The first covers every bankruptcy - over 40,000 in all - in England on a monthly basis from 1862-1866. These data, which were digitized from original sources, report the location and occupation/industry for each bankruptcy filing. Thus, they allow me to track the contemporaneous impact of the Civil War at the level of cities and industries.

Using these data, I investigate bankruptcy patterns around two periods of panic, in Oct. of 1864 and March of 1865, when unexpected news about the Civil War generated panic and many bankruptcies among cotton textile producers. I show that in the month following the panic there were significant increases in bankruptcies in sectors related to the cotton textile industry - particularly the metal \& machinery sector - in the cotton textile towns, controlling for the rate of bankruptcies in this sector in other English cities.

The second data set I draw on describes employment at the city level in 30 industries spanning nearly the entire private sector economy. These data are available for 71 cities from 1851-1871 and 25 cities from 1851-1891. I analyze these data using a panel approach that compares the response of employment in each industry in the cotton textile towns, relative to all other towns, in the post-shock period. This is done while controlling for city-industry fixed effects and time-varying industry effects. My results reveal that the metal \& machinery sector experienced substantially lower employment in the cotton textile towns in the post shock period, relative to non-cotton towns. Thus, it appears that the negative contemporaneous effects revealed by the bankruptcy data also had long-run employment consequences. However, the cotton textile industry itself does not show negative employment effects in the cotton textile towns relative to other cities. This reflects the fact that cotton textile produc- 
ers in every location were directly impacted by the cotton shortage $4^{4}$ In contrast, producers in other industries experienced a differential impact depending on the importance of their links to local cotton textile producers. As a result, metals and machinery producers in the cotton textile towns suffered while their competitors in non-cotton towns did not. The result was a permanent loss of competitiveness, and therefore employment, in these industries in the cotton textile towns relative to firms in the same industries in non-cotton towns 5

My results are related to recent theoretical work that considers the possibility that a shock to one industry (or firm) can generate aggregate effects, if the impacted sector is either large Gabaix (2011)) or connected to many other industries (Acemoglu et al. (2012)). Related empirical work, such as Foerster et al. (2011) and Atalay (2014), uses a model-based approach to identify idiosyncratic shocks in aggregate data in order to assess their importance $5^{6}$ This study takes a different but complementary approach to the same issue. By studying a single well-identified event shock, I provide clear evidence that industry-specific shocks can lead to aggregate effects, at least at the city level. Of course, analyzing the city level is not the same as studying the national economy, but looking at local or regional economies may be a good starting point because it allows me to overcome the degrees-of-freedom problem that often plagues national-level analysis.7 Furthermore, I am also able to provide evidence on the types of inter-industry connections that appear to drive the results I observe. Links to capital suppliers play a key role, while intermediate-goods input-output linkages appear to be less important. Finally, while this literature has tended to focus on contemporaneous aggregate effects, I show that these can also lead to long-run impacts.

This paper is also related to a growing literature on the effect of trade on local labor markets ((Topalova, 2007, 2010; Autor et al., 2012, 2013; Kovak, 2013; Dix-Carneiro \& Kovak, 2014)). An important difference between my paper and previous work in this area is that existing studies tend to focus on changes that are plausibly permanent, at least in the medium term, while the event I consider was widely seen as temporary. Another difference is that I focus on an industry-specific shock, and then trace the impact operating through inter-industry connections. In contrast, previous work tends to focus on changes that occur across many industries with varying intensity, making it difficult to identify the role of interindustry connections. Finally, unlike most studies using modern data, using a historical

\footnotetext{
${ }^{4}$ In fact, historical evidence suggests that smaller cotton textile producers located away from the center of the industry may have been more severely affected by the cotton shortage.

${ }^{5}$ Because industries such as metal and machinery manufacturing produced traded goods, employment will reflect competitiveness in a setting with labor mobility.

${ }^{6}$ These are two recent examples from a larger literature that is too extensive to review here.

${ }^{7}$ This point has previously been made by Autor et al. (2013).
} 
setting allows me to track impacts over several decades following the event $8^{8}$

This study draws on ideas from several recent studies focused on localized inter-industry connections and agglomeration economies ((Ellison et al., 2010; Rosenthal \& Strange, 2004; Greenstone et al., 2010; Hanlon \& Miscio, 2014)). These studies provide evidence that localized inter-industry connections between firms exist and are economically important. This study also finds evidence of such connections, and shows that they play a role in transmitting temporary shocks across sectors.

Methodologically, this study is related to previous work using exogenous changes to local labor demand to study contemporaneous and long-run effects on local production or labor markets ((Carrington, 1996; Black et al., 2005; Hornbeck, 2012)). Finally, this study is related to Hanlon (Forthcoming), which studies the impact of the U.S. Civil War on innovation patterns in the cotton textile industry. ${ }^{9}$

The next section introduces the empirical setting, followed by the data, in Section 3 , the analysis, in Section 4, and conclusions in Section 5.

\section{Empirical setting}

The cotton textile industry was Britain's largest manufacturing sector (by employment) in the second half of the 19th century. In 1861, just prior to the U.S. Civil War, the industry employed 456,646 workers, equal to $2.3 \%$ of the total population or $9.5 \%$ of manufacturing employment. ${ }^{10}$ Cotton textile products were Britain's most valuable export good, while raw cotton was the most important single import.

By the mid-19th century, when our study begins, the cotton textile industry was heavily geographically concentrated in the Northwest region of England, comprised of the counties of Lancashire and Cheshire. According to the 1861 British Census, $82 \%$ of the cotton textile

\footnotetext{
${ }^{8}$ An exception is Dix-Carneiro \& Kovak (2014), which is able to look at outcomes lasting up to 15 years after the end of the trade liberalization that they study. This is still only about half as long as the post-shock period available in my study.

${ }^{9}$ That paper considers the impact of the shift in the relative supply of higher-quality U.S. cotton to lower quality Indian cotton on the rate of innovations related to using these two cotton varieties. The main result is that the shock caused directed technical change towards technologies that enabled British cotton spinners to take advantage of relatively more abundant Indian cotton supplies. Because these innovations took place in a very specific set of cotton-textile-related technologies they are unlikely to have a direct impact on the broad city-level or cross-industry trends considered in this study, other than by reducing somewhat the negative direct impact of the shortage of U.S. cotton on the British cotton textile industry.

${ }^{10}$ This figure includes only those employed in cotton textile manufacturing and excludes other closely related industries such as cotton textile printing (12,556 workers) and cotton textile dying (4,772 workers). Thus, it likely understates the industry's importance.
} 
workers in England and Wales were located in these two Northwest counties 11 In 1851, cotton textile production accounted for $29 \%$ of employment in these counties.

This pattern of concentration dates back to the late 18th century, and perhaps earlier. Using data from the reports generated by the introduction of the Factory Acts in 1838, Crafts \& Wolf (2013) show that this pattern of geographic concentration was related to the availability of water power, the ruggedness of terrain (which decreased the cost of land), proximity to a port (Liverpool), access to markets in other nearby cities, and the area's history of textile innovation in the 18th and early 19th century. While the Northwest region also benefited from access to local coal deposits, many other regions did as well, and Crafts \& Wolf find that this had little impact on the location of the industry by 1838 . By 1850 the importance of initial advantages due to water power and cheap land had largely ceased to matter. Access to markets in other nearby cities was also unlikely to have been an important concern in 1850 given that nearby markets provided only a small fraction of industry demand. Thus, of the initial conditions that drove the location of the industry, only access to the port of Liverpool still mattered by the period we study.

A useful feature of this empirical setting is that we can compare outcomes in the cotton textile towns of Northwest England to outcomes in a set of similar textile-producing towns with industries based on wool, linen, silk and lace, rather than cotton. Many of these other textile towns were also geographically proximate to the Lancashire cotton towns, in nearby Yorkshire County. The second most important textile industry in England during this period was wool textiles. The two branches of this industry, Woolen and Worsted, employed 209,276 workers in 1861, equal to about $1 \%$ of the total population of England and just over $4 \%$ of the industrial workforce. For historical reasons that were likely similar to those that operated in Lancashire, though not as well studied, the industry was heavily concentrated in Yorkshire ${ }^{12}$ Similar patterns hold in silk towns such as Derby, Norwich and Coventry, and in Nottingham, which was a center for lace production. Despite using different inputs, these other textile industries shared many similarities with the cotton textile industry, including their technology, other inputs such as coal and machinery, labor forces, employment practices, and organization. Much of this similarity was driven by the adoption by other textile manufacturers of the innovations generated in the cotton textile industry in the late 18 th and early 19 th century.

\footnotetext{
${ }^{11}$ In a similar vein, Crafts \& Wolf $(2013)$ report that Lancashire County contained $66 \%$ of Britain's cotton textile spindles in 1850 and $79 \%$ in 1903 . Their figures appear to come from the British Parliamentary Papers for those years.

${ }^{12}$ The 1861 census shows that $72 \%$ of the woolen textile workers and $90 \%$ of the worsted textile workers in England and Wales were located in Yorkshire County. Wool textile production accounted for 30\% of employment in the industrialized West Riding region of Yorkshire.
} 
Table 1: Industries with connections to textile production

Intermediate suppliers

- Coal mining

- Chemicals

- Soap

- Oils, paints, dyes

- Rubber

Service suppliers

- Transportation services

- Business services

- Gas, electric, water service
Customer industries

- Clothing manuf.

- Boot and shoe manuf.

- Furniture manuf.

- Paper manuf.

- Other misc. manuf.

Capital suppliers

- Textile machinery

- Steam engines

- Other metal industries

- Construction

This information is drawn from the input-output table constructed by Thomas (1987) and a variety of other historical sources. The list excludes the main intermediate inputs - cotton, wool, flax, and silk - which were not produced in British cities.

The textile industries had links to other upstream and downstream industries which will be important for our analysis. Table 1 describes the key linked industries. Authors such as Allen (2009) have argued that the linkages between the cotton textile industry and other industries, particularly engine and machinery manufacturing, played an important role in the development of the British economy. One consequence of these connections was that, over time, many of these related and supporting industries had become agglomerated in the cotton and other textile towns.

\subsection{Impact of the U.S. Civil War}

Prior to 1861, most of the raw cotton used in England's textile mills was grown in the Southern U.S. The onset of the U.S. Civil War in 1861 created a major disruption of raw cotton supplies. While other major suppliers, such as India and Egypt, did increase production, they were unable to adjust rapidly enough to make up for the sharp fall in U.S. exports. ${ }^{13}$ The left-hand panel of Figure 1 show the effect of the Civil War on British cotton textile imports. The right-hand panel describes domestic raw cotton consumption, the best available measure of production in the industry.

\footnotetext{
${ }^{13}$ Furthermore, the cotton produced by these other suppliers, India in particular, was a lower-quality variety that was an imperfect substitute for the better quality U.S. cotton (see Henderson (1969) (pp. 50-51) and Hanlon (Forthcoming)).
} 
Figure 1: The impact of the U.S. Civil War on the British cotton textile industry
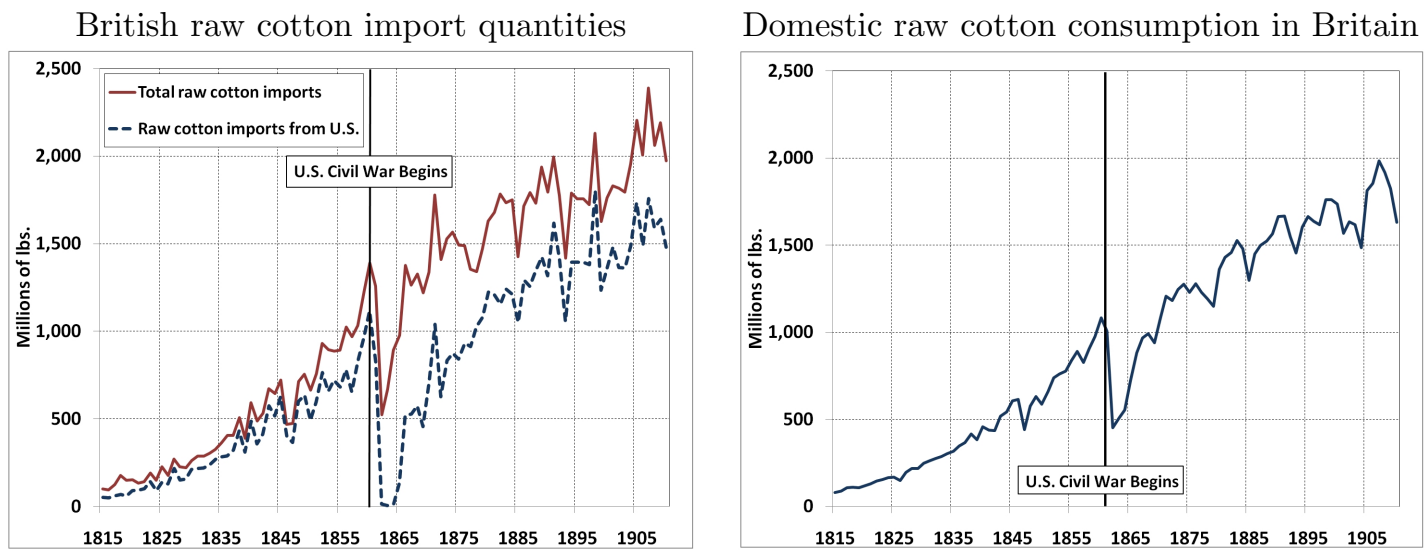

Import data from Mitchell (1988). Domestic raw cotton consumption data, from Mitchell \& Deane (1962), are the best available measure of industry production.

It is clear from these graphs that the U.S. Civil War had a substantial impact on the British cotton textile industry during the 1861-1865 period. The figure also suggests that the impact of the shock on the industry as a whole was temporary and that the resumption of input supplies was matched by a recovery in output by 1870 , followed by a return to consistent growth. There was, however, a change in the source of these input supplies, with cotton from suppliers such as India, Egypt and Brazil making up a much larger share than during the pre-war period.

Figure 2 describes the evolution of the raw cotton price during this period. We can see that the price of raw cotton rose from an average of around 7 pence per pound in the pre-war period to reach a peak of over 30 in 1864. I have highlighted four periods on the graph that will be important for the analysis. The first highlighted region contains the rapid rise and fall of prices in the second half of 1862 that marked the first period of panic in the industry. I have also highlighted the rapid price reductions in Sept. - Nov. 1864 and in Jan. - Apr. 1865. These periods, which I will discuss in more detail later, were characterized by dramatic drops in the price of raw cotton, occurring during a time of great financial uncertainty. The sharp reductions in the cotton price forced many firms holding cotton supplies into bankruptcy. A similar, but less spectacular fall, occurred in Mar. - Jun. 1866. As in 1864-1865, the fall in 1866 was reflected in a large number of bankruptcies, which Henderson (1969) described as "the postponed liquidation of the crisis of 1864." These periods of crisis will be important when we come to the analysis.

There is little evidence that the market anticipated the impact of the Civil War. For example, raw cotton prices show very little increase in the first year of the war. This is 
consistent with the historical record, which suggests that contemporary observers broadly failed to anticipate the length and severity of the Civil War 14

Figure 2: Benchmark cotton prices, 1855-1869

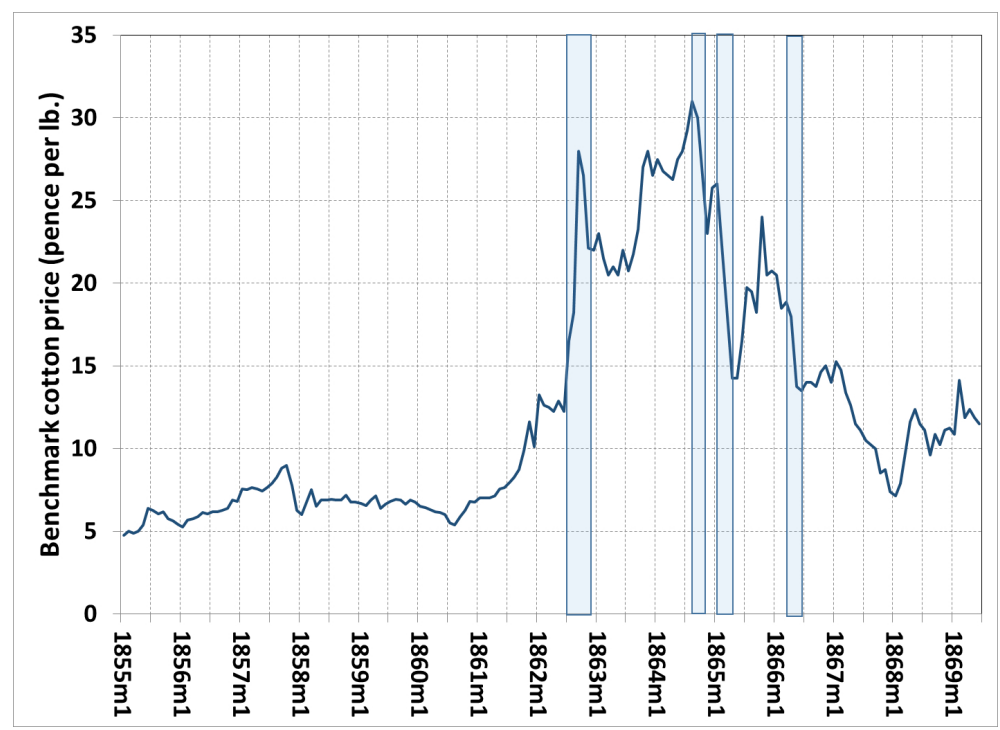

Price data were collected from The Economist magazine. This price is for the benchmark variety, Upland Middling cotton from the U.S., but the prices for other varieties show very similar patterns.

To argue that the U.S. Civil War created a shock that was primarily industry-specific, I look for evidence of other large direct effects of the war. I would expect any such effects to occur either through import or export channels. However, data from Mitchell (1988) (see Figure 6 in the appendix) show that, once raw material for textiles are removed, British imports suffered no noticeable effect from the U.S. Civil War. Similarly, once textile exports are excluded, British exports also show no negative effects. In the armaments and shipbuilding industries, where we would expect the war to have a more direct effect, the impact was substantially muted by Britain's policy of neutrality, which included a prohibition on providing weapons to either side (though we know that some producers managed to circumvent these rules) ${ }^{15}$

\footnotetext{
${ }^{14}$ For example, J.C. Ollerenshaw (1870, p.112), remarked in his presentation to the Manchester Statistical Society that, "The American War commenced on April 5th, 1861, but for many months it had little effect on commerce - being generally regarded as merely temporary..." A striking piece of evidence of this is underestimation of the magnitude of the impending conflict is the fact that the initial Union Army enlistments were for only 90 days; it was assumed that the war would be over before the expired.

${ }^{15}$ One area where there was substantial changes was in ship transport, where many U.S. flagged vessels were transferred to British ownership to avoid Confederate privateers. This may have had an impact on the entrepot trade in port cities. Since none of the textile towns were major trading towns outside of their textile-related imports and exports, this should not be a major concern when I confine the analysis to only
} 
Since I will make a particular comparison between towns specializing in cotton textiles and similar towns specializing in other textile industries, it is worth noting that, unlike cotton, other textile industries experienced little direct impact from the U.S. Civil War. ${ }^{16}$ For example, imports of raw wool were unaffected, since most of these imports come from Spain, Australia, South Africa, or South America. While there was some effect on demand from the U.S., due to tariffs imposed to help fund the war effort, the U.S. was a much smaller market at the time than it is today. Also, exports to European markets increased during the period, particularly to France following a new trade agreement in 1860.

As a result of the geographic concentration of the cotton textile industry, the impact of the shock generated by the Civil War was heavily geographically concentrated. This fact is illustrated in Figure 3 which shows the number of able-bodied workers seeking relief from local Poor Law Boards as a fraction of the total 1861 population, in the cotton region of Northwest England over the shock period. For comparison, the figure includes the fraction of relief seekers in the nearby wool textile region of Yorkshire and in all other English counties over the same period.

Figure 3: Able-bodied relief-seekers as a share of 1861 population in Northwest counties, Yorkshire, and all other English counties

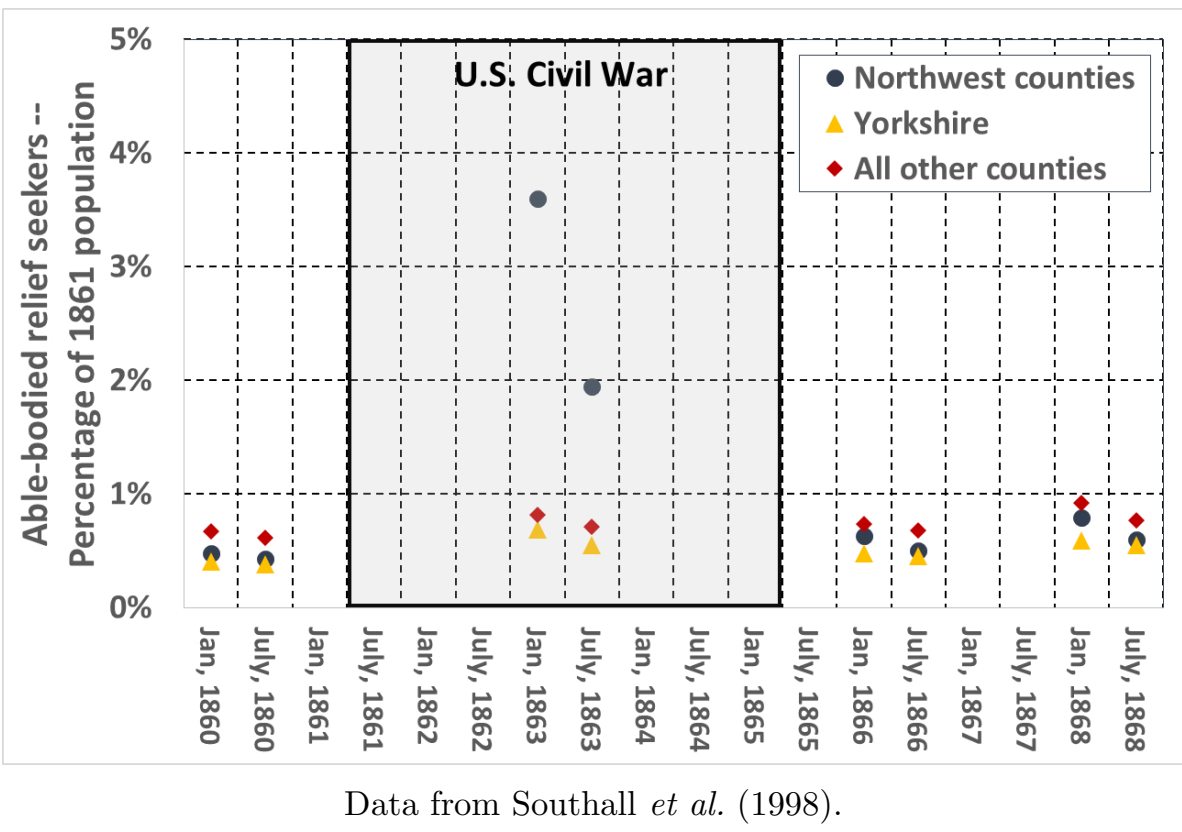

To summarize, the U.S. Civil War generated a large, exogenous, and well-identified shock textile towns.

${ }^{16}$ Data from Mitchell \& Deane 1962$)$. Graphs are available in the Appendix. 
to one important sector of the British economy. The impact of this shock was geographically concentrated in the cotton textile producing towns in the Northwest of England. Other sectors do not show large direct effects from U.S. Civil War. In the next section, I describe the data that I will use to analyze the differential impact of this shock across English cities.

\section{Data}

The first main data set used in this study describes the population of English cities starting in 1841. This new database was collected and digitized from British Census of Population abstracts. The census data were collected every ten years, with the first usable census occurring in 1841. Because these data will be used to analyze patterns of overall city population, it is important that we work with consistent geographic areas. To obtain geographically consistent series, I take advantage of the fact that in each census report the Census Office took the town boundaries for a set of major towns based on that year and then went back to the previous census data and used the more geographically disaggregated data to reconstruct the population within those boundaries in several previous decades. These reconstructed town population data are available in two series, with the first spanning 1841-1891 and 46 cities and the second covering 1851-1901 and 55 cities ${ }^{17}$ Thus, two or three observations are available prior to the U.S. Civil War, and it is possible to track impacts up to 35 years after the War's end 18

To provide further evidence on the impact of the shock on city population, I take advantage of information on the county of birth of the residents in each city reported in the Census of Population Abstracts. These data allow me to estimate the net flows of workers into a town from each other county over the course of each decade.

To analyze the role of specific industries, I use the occupation data, also from the Census of Population reports, covering 1851-1891. The occupation data cover every individual, including women and children, and in the vast majority of cases the reported occupations closely correspond to industries. Examples include "cotton textile spinner", "iron founder", or "boot and shoe maker". Over time, the Census changed the set of occupational categories

\footnotetext{
${ }^{17}$ The data from the 1891 Census, which covers 1841-1891, reports population for 57 major towns based on the 1891 town boundaries. Of these, I am able to identify the share of cotton textiles in total employment in 1851 for 46 towns. The data from the 1901 census reports population for 79 cities for the 1851-1901 period based on 1901 boundaries. Out of these, I can identify the 1851 cotton textile employment share for 55 of these towns.

${ }^{18}$ The 1861 observations were collected before the beginning of the U.S. Civil War and there is little chance that these could have been substantially affected by expectations of the onset of the conflict. Thus, I treat 1861 as a pre-war observation.
} 
reported, so to obtain consistent series I collapse from several hundred categories into 30

private sector industry categories that will be used in the analysis ${ }^{19}$ Table 2 provides an overview of the 30 industries included in the main city-industry dataset.20

Table 2: Industries in the primary analysis database with 1851 employment

$\begin{array}{lrlr}\text { Textile Manufacturing } & & \text { Food, etc. } & \\ \text { Cotton textiles } & 136,041 & \text { Food processing } & 109,541 \\ \text { Wool textiles } & 71,906 & \text { Drinks } & 7,730 \\ \text { Silk textiles } & 37,871 & \text { Tobacconists } & 3,216 \\ \text { Flax/linen textiles } & 14,594 & & \\ \text { Textile finishing, etc. } & 47,456 & \text { Services and Professional } & \\ & & \text { Professionals } & 39,868 \\ \text { Other Manufacturing } & & \text { General services } & 448,499 \\ \text { Chemicals \& drugs } & 17,626 & \text { Merchant, agent, etc. } & 57,126 \\ \text { Clothing, dress, shoes } & 314,440 & \text { Messenger, warehousing, etc. } & 70,778 \\ \text { Instruments \& jewelry } & 30,652 & \text { Shopkeeper, salesmen, etc. } & 26,381 \\ \text { Earthenware \& bricks } & 18,125 & & \\ \text { Leather \& hair goods } & 26,014 & \text { Transportation services } & \\ \text { Metal \& Machinery } & 160,514 & \text { Railway transport } & 9,824 \\ \text { Oil, soap, etc. } & 11,982 & \text { Road transport } & 34,517 \\ \text { Paper and publishing } & 41,505 & \text { Sea \& canal transport } & 61,804 \\ \text { Shipbuilding } & 13,088 & & \\ \text { Vehicles } & 8,531 & \text { Others industries } & \\ \text { Wood \& furniture } & 67,721 & \text { Construction } & 131,714 \\ & & \text { Mining-related } & 22,619 \\ & & \text { Water \& gas services } & 3,821\end{array}$

Employment figures include only the 25 towns available in the 1851-1891 analysis dataset.

The set of towns for which occupational data are reported changes sharply in 1881,

\footnotetext{
${ }^{19}$ These categories exclude agricultural occupations, government workers, non-workers, and a limited number of occupations such as "Labourer" that do not clearly correspond to an industry.

${ }^{20}$ These industries are very similar to those used in Hanlon \& Miscio (2014) except that in this project it is necessary to break out the textile sector into separate series for cotton, wool, linen, and silk textiles. One consequence of this is that the useful data for this project end in 1891; after that date it becomes more difficult to generate consistent series for the separate textile industries. Several of these industries require further explanation. We have to be particularly careful with "Textile finishing, etc." which contains supporting textile-related industries such as bleaching and dying, small textile sectors such as ribbon or lace making, and textile workers that did not report their particular branch. The service industries are also somewhat complex. The "Messenger, warehousing, etc.," for example, contains a variety of communication and storage-related work. The category "Merchant, agent, etc." contains all business services (including, e.g., accountants and brokers). "Professionals" is made up primarily of lawyers and doctors. The "Chemicals \& drugs" industry contains some intermediate cotton textile inputs such as dyes. "Oil, soap, etc." also provided inputs, such as rubber goods, to cotton textile production.
} 
when the census office begins reporting these data only for towns with a population over 50,000. Thus, I will conduct analysis using two sets of city-industry data. One data set covers 1851-1871 and includes 71 towns, with 8 towns specializing in cotton textiles and 10 towns specializing in non-cotton textile products. The second data set covers 1851-1891 and includes 25 towns, with 6 towns specializing in cotton and 6 towns specializing in non-cotton textile products.

In addition to the Census data, I will also draw on a new set of data covering all bankruptcies in England from 1862-1866. These data provide a uniquely rich and comprehensive way to track one important aspect of the shock in real-time. The roughly 40,000 bankruptcies in the database that I construct were hand-entered from announcements printed in the London Gazette, England's official government register. These data are available on a monthly basis and include the name, location, and occupation of the bankrupt individual. The original data report around 15,000 unique occupations, which I have classified by hand into industry categories that reflect those available in the Census data (Table 2).

There are a few important facts to keep in mind when using the bankruptcy data. First, there was a major change in bankruptcy law that came into effect in November of 1861. This change expanded bankruptcy to cases where it had not applied before, leading to very high levels of bankruptcy in late 1861 and 1862. As a result, in the analysis I use data starting in June, 1863, when bankruptcies had returned to more normal levels. Second, these were personal bankruptcy filings in a time in which the vast majority of firms were privately owned. Thus, they will capture substantially all firm bankruptcies, but they may also include bankruptcies by individuals who are not firm owners. For example, the category of cotton textile related bankruptcies can include both the bankruptcy of a firm owner and the bankruptcy of a foreman at the firm. Thus, the bankruptcy counts may not reflect the wide variation in the size of the bankruptcy they reflect; the bankruptcy of a major cotton manufacturer will look the same as the bankruptcy of a one-man shop. Unfortunately, because we do not know the size of the bankruptcy it is not possible to adjust for these differences. ${ }^{21}$ Despite these issues, we will see that the bankruptcy data can still help shed light on the impact of the Civil War shock.

\footnotetext{
${ }^{21}$ This is very similar to the problem regularly encountered when using patent data. The solution in that setting is to use additional information to adjust for the quality differences across patents. Unfortunately I have not found a good way to adjust the bankruptcy counts for the importance of individual filings.
} 


\section{Analysis}

This section begins with an analysis of the impact of the U.S. Civil War on overall population growth in cotton textile towns relative to other towns in England. I then turn to the analysis of the role of industries in generating these effects.

\subsection{Patterns of town population growth}

A good starting point for understanding the impact of the shock on city population growth is to look at the average growth rates in the cotton towns and all of the other towns over each decade in the 1841-1891 period. This is done in Table 3 using 46 towns. There are ten cotton towns, defined as those with more than 10 percent of the working population employed in the cotton textile industry in 1851. ${ }^{22}$ There are eight other textile towns, defined as those with more than 10 percent of the working population employed in any textile industry and less than 10 percent employed in cotton textiles. In practice, these towns are dominated by other textile industries and have fairly low levels of cotton textile employment (never more than $2.8 \%$ ). These definitions will be used throughout the paper.

The first pattern to take away from Table 3 is that, relative to all other towns or to just other textile towns, the cotton towns in the Northwest of England suffered slower growth in the 1861-1871 period. This was a reversal of the previous trend of faster growth in cotton towns. After 1871, we see that growth in the cotton towns rebounds, but does not overshoot, suggesting that population in these downs did catch-up after the shock, at least through 1891.

Table 3: Average decadal population growth in towns

\begin{tabular}{lccccc}
\hline \hline & $1841-1851$ & $1851-1861$ & $1861-1871$ & $1871-1881$ & $1881-1891$ \\
\hline All towns (47) & $25.1 \%$ & $22.2 \%$ & $19.1 \%$ & $20.2 \%$ & $19.9 \%$ \\
Cotton towns (10) & $22.3 \%$ & $20.4 \%$ & $10.8 \%$ & $18.3 \%$ & $13.0 \%$ \\
Other textile towns (8) & $19.0 \%$ & $12.2 \%$ & $16.2 \%$ & $17.5 \%$ & $13.3 \%$ \\
Non-textile towns(29) & $25.8 \%$ & $22.7 \%$ & $21.3 \%$ & $20.8 \%$ & $21.8 \%$ \\
\hline \hline
\end{tabular}

The cotton towns are identified as those with more than 10 percent of the working population employed in the cotton textile industry in 1851. The cotton towns are Blackburn, Bolton, Burnley, Bury, Manchester, Oldham, Preston, Rochdale, Stockport and Wigan, which are all in Lancashire or Cheshire. The other textile towns are identified as those with more than 10 percent of the working population employed in any textile industry and less than 10 percent employed in cotton textiles. The other textile towns and their main products are Huddersfield (wool), Halifax (wool), Bradford (wool), Leeds (wool), Derby (silk), Norwich (silk), Nottingham (lace), and Coventry (silk).

\footnotetext{
${ }^{22}$ This is a natural cutoff point, since there is a sharp drop-off in the share of cotton textiles in town employment from Wigan, with $16.5 \%$, to Warrington, with $7 \%$.
} 
Figure 4 allows us to compare population growth in cotton towns compared other textile towns over the study period. This figure presents the sum of log population for the cotton and other textile towns across the entire 1841-1891 period. ${ }^{23}$ This graph shows that there was little change in the population growth rate in the other textile towns over this period, so that a trend-line based on the 1841-1861 period predicts population through 1891 reasonably well. For the cotton towns, we can see that the trend is fairly constant in the 1841-1861 period, but slows substantially between 1861-1871. There is also weak evidence that population growth remained lower in the cotton textile towns after 1871 than would have been predicted based on the initial growth trend.

Figure 4: Population growth in cotton and other textile towns

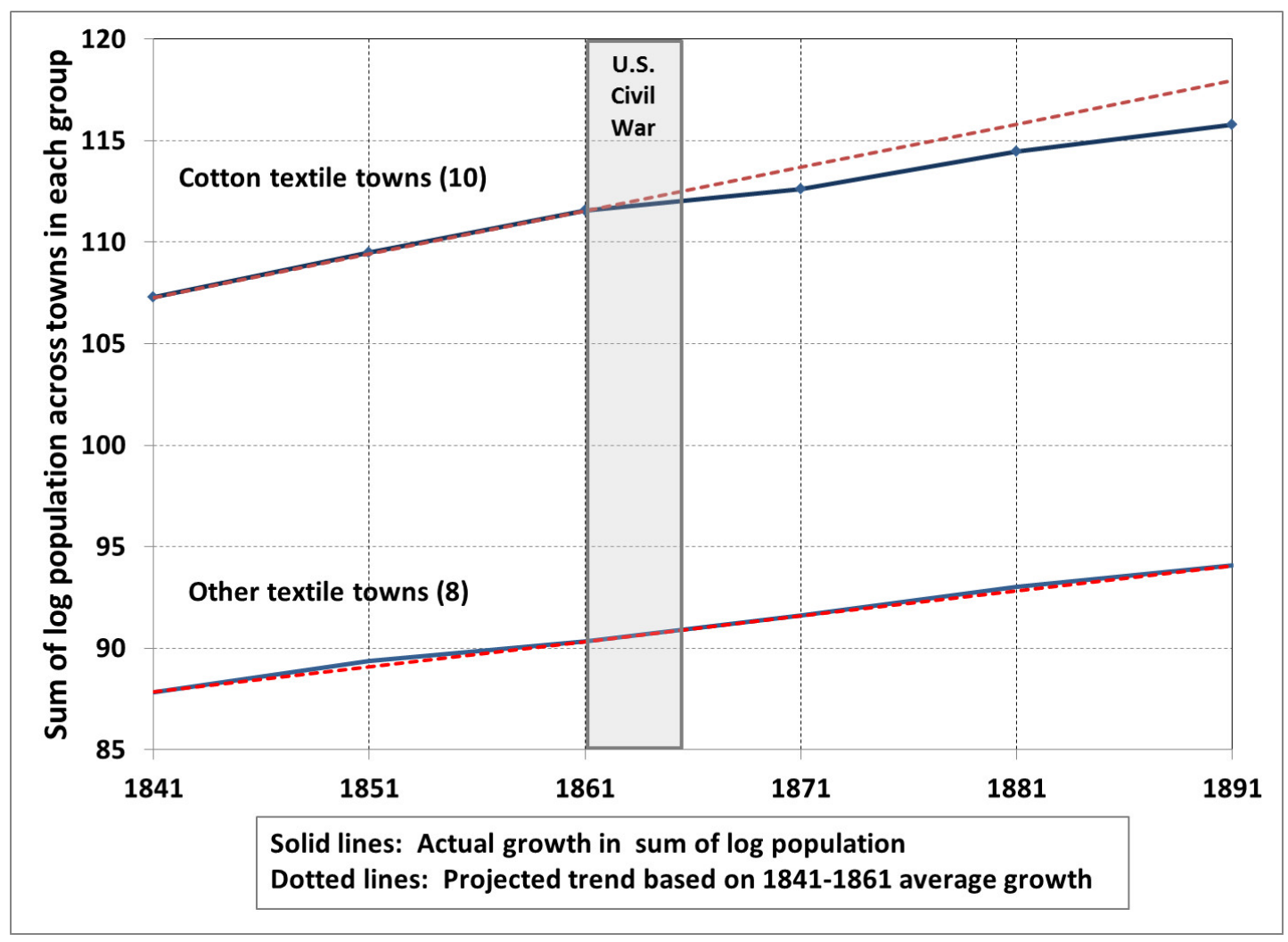

Next, I explore these patterns using a regression approach. The baseline regression specification I consider is,

\footnotetext{
${ }^{23}$ Using the sum of log population here ensures that the patterns are not dominated by the large cities. It also matches my empirical approach.
} 


$$
\ln \left(P O P_{c t}\right)-\ln \left(P_{c t-1}\right)=\beta_{0}+\beta_{1}\left(\text { CottonTOWN } N_{c} * S_{\text {hock }}\right)+\gamma_{c}+\lambda_{t}+e_{i t}
$$

where $P O P_{c t}$ is the population of city $c$ in period $t, S h o c k_{t}$ is an indicator variable for the shock period, $\gamma_{c}$ is a full set of city fixed effects, and $\lambda_{t}$ is a full set of time effects.

The coefficient of interest in these regressions is $\beta_{1}$. In interpreting this coefficient, it is important to keep in mind that, because all towns are operating within a connected economic system, a negative shock to the cotton textile towns may generate positive effects for the non-cotton towns. Thus, the $\beta_{1}$ coefficient will reveal the change in relative growth rates between cotton and non-cotton towns generated by the shock, which will be composed of both the negative effects in the cotton towns and any positive impact of the shock on noncotton towns. Thus, this estimate will likely be larger than the change in the growth rate of the cotton towns relative to their counterfactual growth in the absence of the shock.

Spatial correlation is a potential concern in this setting. To deal with this, I estimate standard errors robust to spatial correlation up to $100 \mathrm{~km}$ based on Conley (1999) These spatial-correlation-robust standard errors are generally lower than the heteroskedasticityrobust standard errors, suggesting that errors are negatively spatially correlated. Thus, I also present standard robust standard errors for all specifications. While serial correlation can be an issue in panel data settings (Bertrand et al. (2004)), this is less likely to be a major concern for the current study given the relatively short time dimension in the data.

Table 4 describes results generated for different time periods using the specification in Equation 1. Heteroskedasticity-robust standard errors are reported in single parentheses, while spatial-correlation-robust standard errors are in double parentheses. Because I present multiple standard errors for each regression, I will not follow the standard practice of using * to indicate statistical significance levels.

\footnotetext{
${ }^{24}$ To implement this approach I follow Hsiang (2010). I have experimented with allowing correlation over different distances and I did not find that this substantially affected the confidence intervals. I have also experimented with allowing limited serial correlation based on the method from Newey \& West (1987) and this also does not seem to substantially impact the results.
} 
Table 4: Regressions of population growth in cotton vs. all other towns

\begin{tabular}{|c|c|c|c|c|c|c|}
\hline & \multicolumn{6}{|c|}{ DV: Town population growth rate in each decade } \\
\hline & (1) & $(2)$ & $(3)$ & (4) & $(5)$ & (6) \\
\hline $\begin{array}{l}\text { Years } \\
\text { included: }\end{array}$ & 1841-1861 & 1851-1871 & $1841-1871$ & 1841-1891 & 1841-1891 & 1851-1901 \\
\hline $\begin{array}{l}\text { Cotton towns } \\
\text { in } 1851-1861\end{array}$ & $\begin{array}{c}0.0161 \\
(0.0349) \\
((0.0223))\end{array}$ & & & & $\begin{array}{c}0.0161 \\
(0.0351) \\
((0.0271))\end{array}$ & \\
\hline $\begin{array}{l}\text { Cotton towns } \\
\text { in } 1861-1871\end{array}$ & & $\begin{array}{c}-0.0864 \\
(0.0271) \\
((0.0119))\end{array}$ & $\begin{array}{c}-0.0783 \\
(0.0293) \\
((0.0192))\end{array}$ & $\begin{array}{c}-0.0783 \\
(0.0294) \\
((0.0186))\end{array}$ & $\begin{array}{c}-0.0702 \\
(.0401) \\
((0.0246))\end{array}$ & $\begin{array}{c}-0.0799 \\
(0.0271) \\
((0.0217))\end{array}$ \\
\hline $\begin{array}{l}\text { Cotton towns } \\
\text { in } 1871-1881\end{array}$ & & & & $\begin{array}{c}-0.0056 \\
(0.0311) \\
((0.0188))\end{array}$ & $\begin{array}{c}0.0024 \\
(0.0406) \\
((0.0247))\end{array}$ & $\begin{array}{c}0.0015 \\
(0.0312) \\
((0.0190))\end{array}$ \\
\hline $\begin{array}{l}\text { Cotton towns } \\
\text { in } 1881-1891\end{array}$ & & & & $\begin{array}{c}-0.0111 \\
(0.0338) \\
((0.0219))\end{array}$ & $\begin{array}{c}-0.0030 \\
(0.0403) \\
((0.0272))\end{array}$ & $\begin{array}{c}-0.0045 \\
(0.0377) \\
((0.0191))\end{array}$ \\
\hline $\begin{array}{l}\text { Cotton towns } \\
\text { in } 1891-1901\end{array}$ & & & & & & $\begin{array}{c}-0.0462 \\
(0.0417) \\
((0.0175))\end{array}$ \\
\hline City FEs & Yes & Yes & Yes & Yes & Yes & Yes \\
\hline Time effects & Yes & Yes & Yes & Yes & Yes & Yes \\
\hline Observations & 92 & 92 & 138 & 230 & 230 & 275 \\
\hline Cities & 46 & 46 & 46 & 46 & 46 & 55 \\
\hline $\begin{array}{l}\text { Heteroskedasti } \\
\text { spatial correla } \\
\text { of city fixed ef } \\
\text { census coverin } \\
\text { set from the } 1\end{array}$ & $\begin{array}{l}\text {-robust } \\
\text { up to } 1 \\
\text { and yea } \\
41-1891 \text {. } \\
\text { census ce }\end{array}$ & $\begin{array}{l}\text { idard er } \\
\mathrm{m} \text { in do } \\
\text { fects. T } \\
\text { he resul }\end{array}$ & $\begin{array}{l}\text { in parer } \\
\text { parenth } \\
\text { egression } \\
\text { column }\end{array}$ & $\begin{array}{l}\text { es. HAc } \\
\text { All spe } \\
\text { columns } \\
\text { re based }\end{array}$ & $\begin{array}{l}\text { standard } \\
\text { ications il } \\
-5 \text { use dat } \\
\text { a slightl }\end{array}$ & $\begin{array}{l}\text { s robust to } \\
\text { de a full set } \\
\text { m the } 1891 \\
\text { fferent data }\end{array}$ \\
\hline
\end{tabular}

The first column reports results from a placebo test using only data from 1841-1861, prior to the war. We can see that the cotton towns do not exhibit differential growth patterns during this pre-period. The second column compares the decades just before and just after the war. There is clear evidence that the rate of population growth in the cotton towns fell in the 1861-1871 period. Column 3 expands the pre-period to include 1841-1851. The results in both columns 2 and 3 are statistically significant at the standard $95 \%$ confidence level. Columns 4 and 5 use the full set of available data and estimate separate impacts for the 1871-1881 and 1881-1891 periods. Here, we are looking for evidence that the cotton towns experienced faster growth after 1871 which might have allowed them to catch-up to their previous growth path. The results provide no evidence that any such catch-up took place, at least before 1891. This suggests that reduced growth in 1861-1871 generated a persistent 
effect on the level of population in the cotton producing towns.

The results in Table 4 include the full set of towns for which sufficient data are available. A potential concern here, as in all difference-in-difference analysis, is the parallel trends assumption; for the procedure to deliver reliable results, the growth path of the untreated towns, controlling for their initial growth rate, must provide a valid counterfactual for the treated towns. We may worry that there is substantial variation in the underlying characteristics of the cities that may lead to this assumption being violated. Seaports, for example, may not be a good counterfactual for inland industrial towns. One way to address this concern is to confine the analysis to a subset of towns that are more similar to the treated towns. This can strengthen our confidence in the parallel trends assumption, but it comes at the cost of working with a somewhat reduced sample size.

Table 5 presents results calculated by comparing the 10 cotton textile towns to the 8 other towns where (non-cotton) textile production formed an important part of the economy. These towns are economically very similar to the cotton textile towns. This table shows that I obtain even stronger results when comparing the cotton textile towns to this subset of economically similar towns.

To further support these findings, I can draw on information on the movements of workers between locations provided by the Census of Population. The census data can help reveal migration patterns within England because the population enumerated in a particular location are asked their location of birth. Substantial changes in the population of one county or town that report a county of birth in another can then be used as an indicator of net population flows between locations. 
Table 5: Regressions of population growth in cotton vs. other textile towns

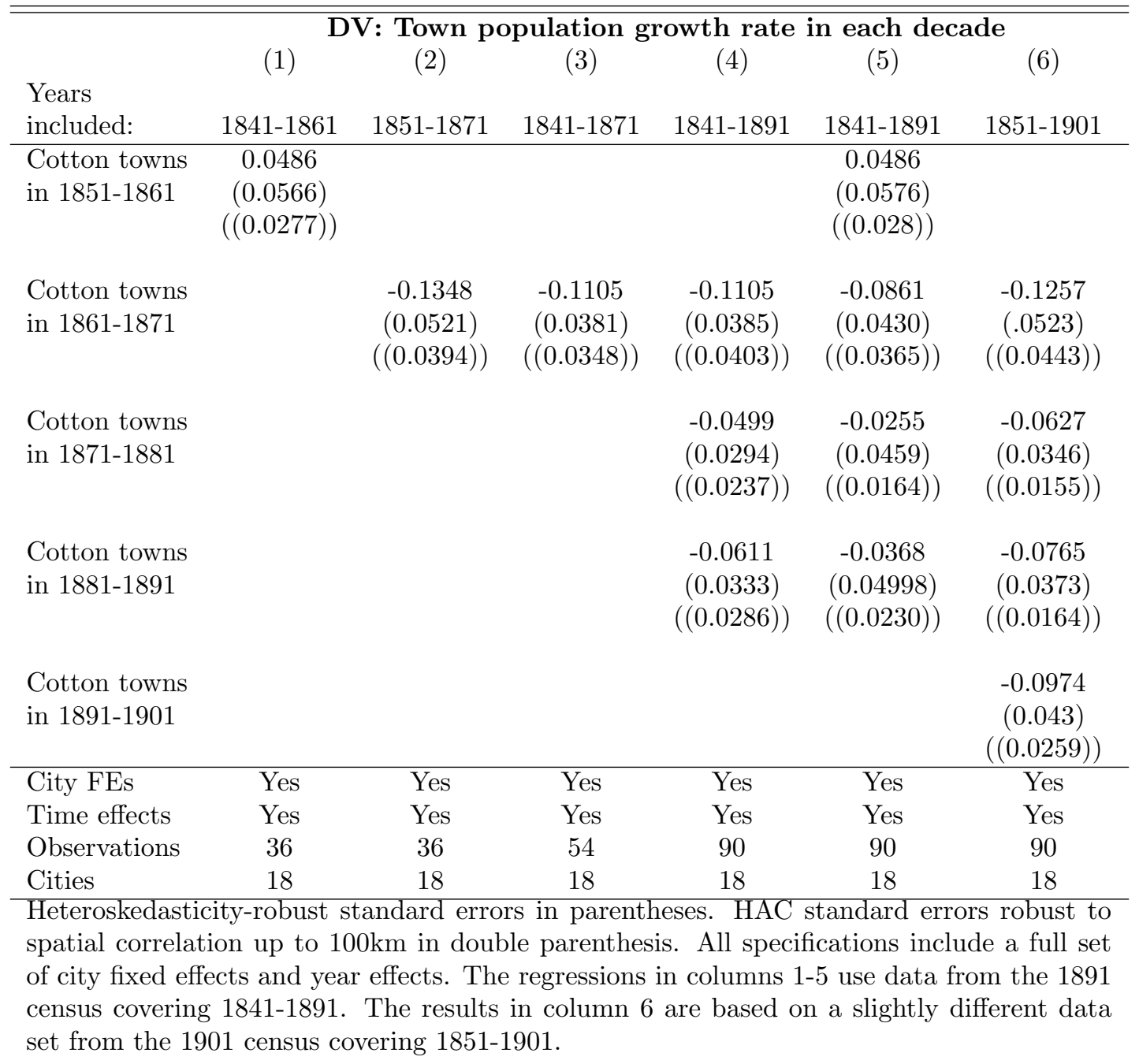

Figure 6 plots the number of residents of other English counties who were born in the Northwestern Counties (Lancashire and Cheshire) in each year. We can see that the Civil War period was characterized by a sharp increase in residents of other counties who were born in the Northwest, suggesting that out-migration took place during this period. The number of people born in the Northwest but living in other counties increased by around 21,000 from $1861-1871$, equal to a movement of about $0.7 \%$ of the 1861 population or $1.4 \%$ of the 1861 working population of the Northwest counties. This compares to an increase of just over 1,600 from 1851-1861. Note that, because these data span the 1861-1871 decade, they will understate migration during the shock period if it was accompanied by return migration before 1871. 
Table 6: Residents of other English counties that were born in the Northwest region

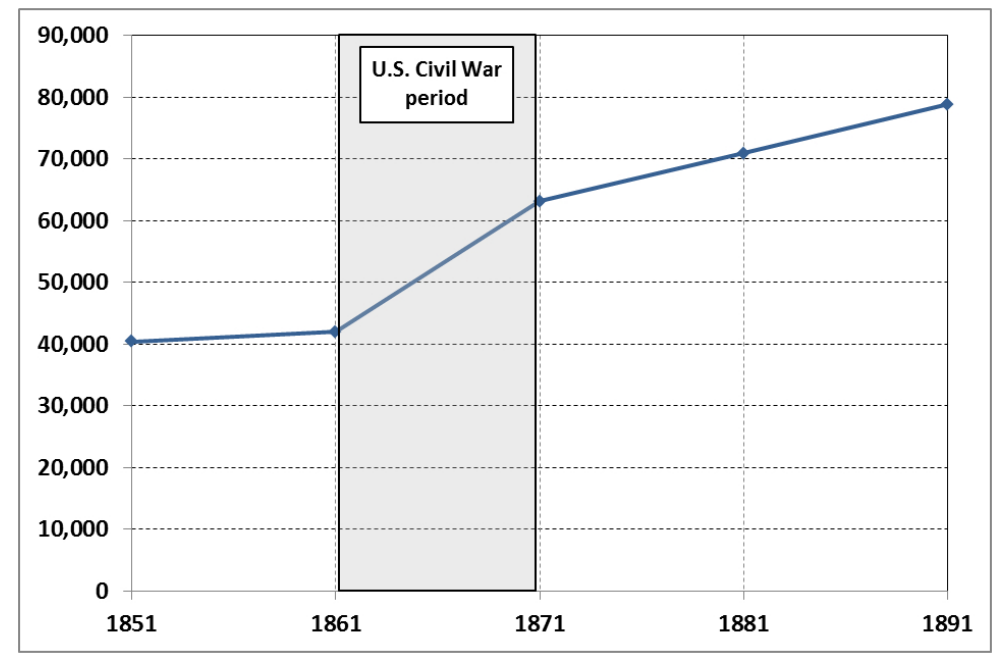

Data collected from Census of Population reports.

Much of this out-migration flowed to the textile and industrial districts of nearby Yorkshire county $\left[{ }^{25}\right.$ Figure 7 describes the change in the number of Northwest residents reporting Yorkshire as the location of birth and Yorkshire residents reporting the Northwestern counties as a location of birth. Both of these series reflect the net migration from Lancashire to Yorkshire during the Civil War period, and we can see that the original patterns of migration resume after 1871 but that there is no evidence of the overshooting needed to return the locations to the original growth path. Thus, the shock period generated a persistent shift in the relative position of the two lines, suggesting that the migration flows that occurred in the 1861-1871 period were not reversed in later decades.

\footnotetext{
${ }^{25} \mathrm{~A}$ number of factors may have contributed to the migration flows out of the Northwest region in response to the Civil War shock. One likely contributing factor is the relatively modest level of transfer payments available at the time. While this period marked a turning point in the development of the British system of Poor Relief, aid remained primarily for the truly destitute. Another potential driver was the availability of less-affected cities close to the cotton towns, many with jobs matching the skills of the displaced workers. In Appendix A.3 I explore a number of factors that might have contributed to these migration flows. I find that three factors - geographic proximity to the cotton towns, the initial population of Northwest residents in a town, and the share of town employment in other textile industries - are correlated with the size of migration flows to the non-cotton towns. Among these, geographic proximity appears to be the dominant factor determining the destination of migrants leaving the cotton textile towns during the 1861-1871 decade.
} 
Table 7: Residents of the Northwest and Yorkshire born in the other region

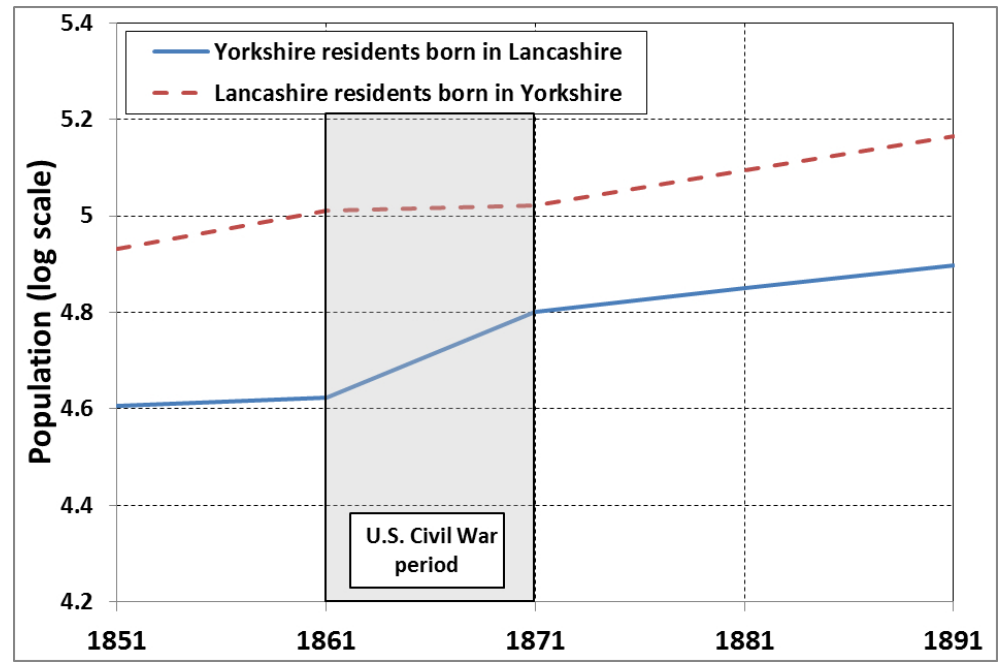

Data collected from Census of Population reports.

This section has provided evidence that population growth in cotton textile towns was reduced in the 1861-1871 period relative to other British towns. There is no evidence of higher growth in the years after 1871 that would suggest catch-up to the initial growth path. Migration data confirms the increased outflow and decreased inflow of residents behind the city-size effects. In the next section, I unpack the overall city effects by looking at the role played by specific industries and the connections between them.

\subsection{Decomposing effects by industry}

This section explores the role of industries in generating the persistent city-size effect documented in the previous section. The analysis proceeds in four parts. First, using Census of Population data I consider the contribution of different industrial sectors to growth in the cotton textile towns and compare this to the pattern observed in other towns. In the second step, I draw on the bankruptcy data to show how shocks to the cotton textile industry led to bankruptcies in other related industries during the Civil War period. I then return to the Census of Population data to look at whether similar patterns appear when we look at industry outcomes in the long-run. Finally, because I observe particularly strong effects among metal \& machinery producing firms, I provide some further evidence on the patterns observed in this industry.

My starting point is Table 8, which uses the Census of Population data to decompose city employment growth into the contribution of broad sectors of the city economies. The 
tables is read as follows: if an industry represents $10 \%$ of employment in a set of towns at the beginning of the decade, and grows by $10 \%$ over the course of the decade in those towns, then the contribution of that industry to employment growth in that set of towns is 1\%. Thus, the figures in this table reflect both the initial size and the growth rate of each sector of the economy, which together determine the sector's contribution to city employment growth. The first panel focuses on the six cotton textile towns available in the 1851-1891 city-industry database. The second panel conducts a similar exercise for the non-cotton textile towns, while the last panel includes all towns other than the cotton textile towns.

In the cotton textile towns, employment growth prior to the U.S. Civil War was driven by cotton textile manufacturing and other non-textile manufacturing (highlighted rows). However, the growth contribution made by the cotton textile industry dropped sharply starting in 1861-1871. Clearly the direct shock to the cotton textile industry had an important effect on overall employment growth in these towns. The contribution of cotton textile to employment growth continued to fall in 1871-1881. This was due in part to poor macroeconomic conditions from 1873-1879, a period called the "Long Depression". Cotton textiles employment growth then recovered after 1881.

Importantly, employment growth in non-textile manufacturing industries also slowed down substantially during the 1861-1871 period. This fall cut an average of over $4 \%$ off of employment growth in the cotton textile towns, which is roughly as large as the direct impact of the cotton textile industry itself. Non-textile manufacturing growth then increased after 1871, but the growth contribution of this sector remained below the initial rate through 1891 . This pattern suggests that the shock had an important indirect effect on city growth in the cotton textile towns, through these other manufacturing industries. Comparing this pattern that observed in the bottom panel (highlighted row) shows that the reduced growth in the non-textile manufacturing sector in the cotton textile towns was not driven by national-level changes in the growth contribution of this sector.

The story is quite different in the other textile towns described in the middle panel. There, the 1861-1871 period was characterized by a sharp increase in growth in non-cotton textile manufacturing. An even more interesting pattern is visible for the non-textile manufacturing industries, which experienced a substantial increase in their growth contribution in 18611871 and a sustained higher level through 1891. This persistent increase contrasts with the persistent decrease in non-textile manufacturing experienced in the cotton textile towns. 
Table 8: Decomposing the growth contribution by sector

\begin{tabular}{lrrrr}
\hline \multicolumn{4}{c}{ Cotton textile towns (6 towns) -- growth contribution of each sector } \\
\hline & $1851-1861$ & $1861-1871$ & $1871-1881$ & $\frac{1881-1891}{3}$ \\
\cline { 2 - 5 } Cotton textiles & $7.30 \%$ & $2.94 \%$ & $-2.54 \%$ & $3.55 \%$ \\
Other textiles & $0.03 \%$ & $0.82 \%$ & $-1.06 \%$ & $-0.22 \%$ \\
Manufacturing (non-textile) & $6.43 \%$ & $1.88 \%$ & $3.86 \%$ & $5.18 \%$ \\
Food processing & $0.74 \%$ & $0.80 \%$ & $0.64 \%$ & $1.52 \%$ \\
Mining related & $0.19 \%$ & $0.33 \%$ & $0.04 \%$ & $0.25 \%$ \\
Transportation & $1.17 \%$ & $1.81 \%$ & $1.83 \%$ & $2.71 \%$ \\
Business services & $-0.31 \%$ & $1.65 \%$ & $1.80 \%$ & $1.22 \%$ \\
Professions & $0.58 \%$ & $0.35 \%$ & $0.75 \%$ & $0.71 \%$ \\
Construction & $1.17 \%$ & $1.11 \%$ & $0.30 \%$ & $0.51 \%$ \\
General services & $1.50 \%$ & $3.89 \%$ & $-2.59 \%$ & $1.37 \%$ \\
Government & $-0.13 \%$ & $0.14 \%$ & $0.20 \%$ & $0.26 \%$ \\
\hline
\end{tabular}

\begin{tabular}{|c|c|c|c|c|}
\hline \multicolumn{5}{|c|}{ Other textile towns (6 towns) -- growth contribution of each sector } \\
\hline & $\underline{1851-1861}$ & $\underline{1861-1871}$ & $\underline{1871-1881}$ & $\underline{1881-1891}$ \\
\hline Cotton textiles & $3.48 \%$ & $-0.28 \%$ & $1.16 \%$ & $0.77 \%$ \\
\hline Other textiles & $-1.15 \%$ & $14.32 \%$ & $-9.31 \%$ & $2.12 \%$ \\
\hline Manufacturing (non-textile) & $3.71 \%$ & $7.60 \%$ & $6.22 \%$ & $6.19 \%$ \\
\hline Food processing & $1.04 \%$ & $1.50 \%$ & $1.08 \%$ & $1.55 \%$ \\
\hline Mining related & $0.74 \%$ & $0.77 \%$ & $0.82 \%$ & $0.59 \%$ \\
\hline Transportation & $0.64 \%$ & $1.73 \%$ & $1.71 \%$ & $2.01 \%$ \\
\hline Business services & $0.40 \%$ & $1.28 \%$ & $1.59 \%$ & $1.10 \%$ \\
\hline Professions & $0.62 \%$ & $0.71 \%$ & $1.17 \%$ & $0.81 \%$ \\
\hline Construction & $1.09 \%$ & $2.46 \%$ & $1.13 \%$ & $0.24 \%$ \\
\hline General services & $2.50 \%$ & $4.11 \%$ & $0.89 \%$ & $1.42 \%$ \\
\hline Government & $0.05 \%$ & $0.22 \%$ & $0.40 \%$ & $0.24 \%$ \\
\hline \multicolumn{5}{|c|}{ All non-cotton towns (18 towns) -- growth contribution of each sector } \\
\hline & $\underline{1851-1861}$ & $\underline{1861-1871}$ & $\underline{1871-1881}$ & $\underline{1881-1891}$ \\
\hline Cotton textiles & $3.13 \%$ & $-1.75 \%$ & $-0.38 \%$ & $0.21 \%$ \\
\hline Other textiles & $0.06 \%$ & $1.49 \%$ & $-0.84 \%$ & $0.38 \%$ \\
\hline Manufacturing (non-textile) & $6.40 \%$ & $4.38 \%$ & $4.81 \%$ & $5.40 \%$ \\
\hline Food processing & $1.17 \%$ & $1.20 \%$ & $0.83 \%$ & $1.63 \%$ \\
\hline Mining related & $0.26 \%$ & $0.26 \%$ & $0.09 \%$ & $0.27 \%$ \\
\hline Transportation & $1.66 \%$ & $2.20 \%$ & $2.40 \%$ & $3.27 \%$ \\
\hline Business services & $0.59 \%$ & $1.88 \%$ & $2.32 \%$ & $1.47 \%$ \\
\hline Professions & $1.04 \%$ & $0.68 \%$ & $1.26 \%$ & $1.11 \%$ \\
\hline Construction & $1.13 \%$ & $1.71 \%$ & $1.02 \%$ & $0.28 \%$ \\
\hline General services & $3.43 \%$ & $4.66 \%$ & $0.72 \%$ & $2.17 \%$ \\
\hline Government & $0.14 \%$ & $0.50 \%$ & $0.42 \%$ & $0.50 \%$ \\
\hline
\end{tabular}

Each cell of these tables represents the contribution of an industry to city growth over the period indicated. So if an industry represents $10 \%$ of employment and grows $10 \%$ over the period, that industry's contribution to city growth is $1 \%$. Thus, the column sum of each table equals the total growth of the group of towns over the period. Note that the column sums will differ from those in Table 3 both because we are working with a different set of cities and because they represent employed population rather than total population.

This table reveals that only about half of the reduction in employment growth in the 
cotton textile towns from 1861-1871 was due to the losses in the cotton textile industry itself. Other industries - specifically non-textile manufacturing sectors - played an equally important role. In the remainder of this section, I investigate the role that linkages between the cotton textile industry and other sectors played in generating these effects.

I begin by considering patterns during the shock period using the bankruptcy data, which start in the middle of 1863 and continue through the end of 1866 . Figure 5 describes the pattern of bankruptcies in cotton textiles (solid line) and in related sectors (stacked bars) in major cotton textile towns during this period 26 We can see that there were three periods with high levels of bankruptcies in the cotton textile sector over this time frame. ${ }^{27}$ These correspond to the three periods in which the price of cotton rapidly declined (recall Figure 2).

Figure 5: Bankruptcies in major cotton textile towns

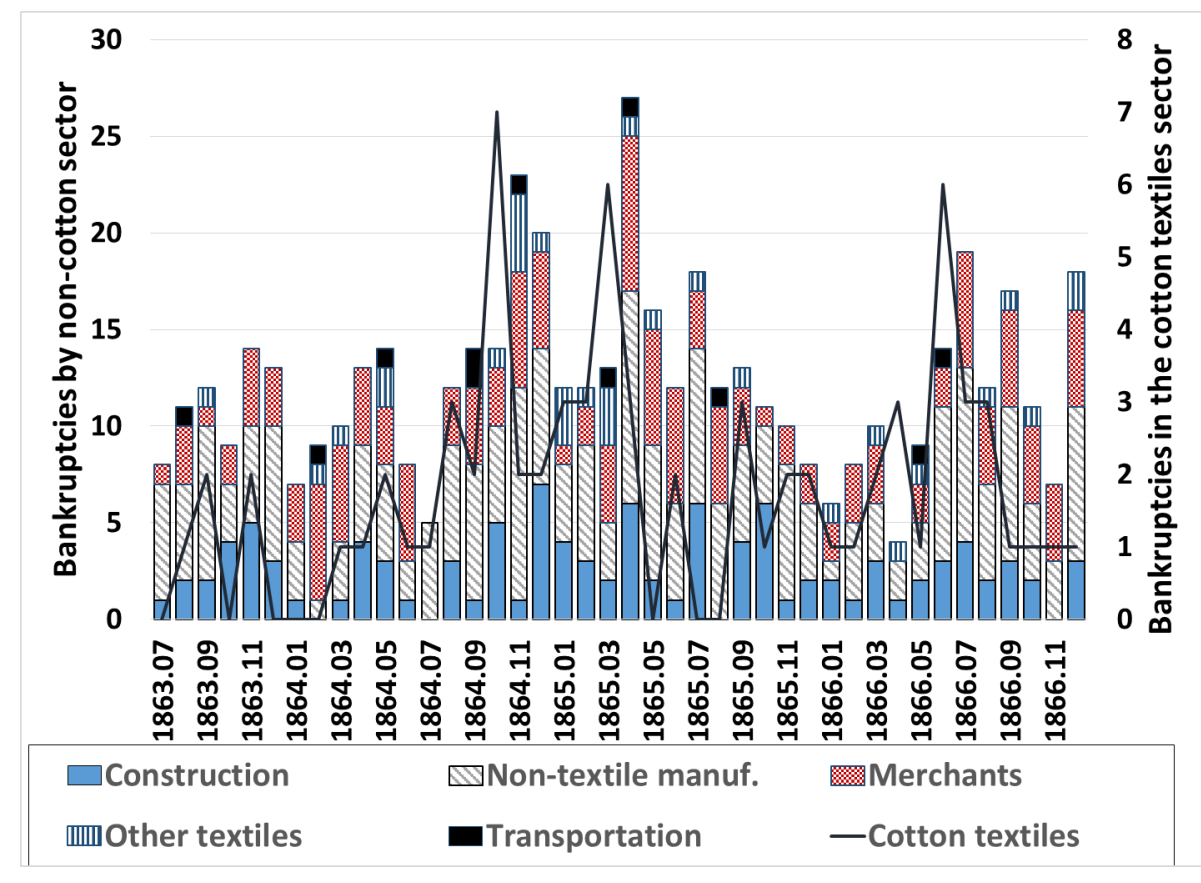

The bar chart (left-hand axis) describes bankruptcies in a number of industrial sectors related to cotton textiles. Solid line (right-hand axis) describes the number of bankruptcies in the cotton textile sector. The cotton textile towns included in this chart are Accrington, Ashton-under-Lyne, Blackburn, Bolton, Burnley, Bury, Manchester, Oldham, Preston, Rochdale, Warrington, Wigan, Stockport and Chester. All of these are in Lancashire except for the last two, which are in Cheshire.

\footnotetext{
${ }^{26}$ This figure excludes a large number of bankruptcies by shopkeepers, beer sellers, farmers, government employees and other miscellaneous sectors. Figure 12 in Appendix A.4 shows that there is at most a weak relationship between bankruptcies in these other sectors and bankruptcies in the cotton textile industry.

${ }^{27}$ There is also evidence of a high level of cotton textile bankruptcies in 1862 , but it is difficult to be sure that these were not related to the new bankruptcy law passed in 1861.
} 
This figure shows a fairly clear pattern in which sharp increases in bankruptcies in the cotton textile sector were accompanied, usually with a one-month lag, by spikes in bankruptcies in other industrial sectors. Many of these additional bankruptcies are in the non-textile manufacturing industries, though smaller increases also appear in construction, merchants, and other textile industries.

It is worth pausing now to consider the historical record on the causes of these large spikes in cotton textile industry bankruptcies. The first and largest increase, in October of 1864, has been called the "peace panic" (Watts (1866)) because it was generated by rumors that a peaceful end to the Civil War was being negotiated. Watts (1866) (p. 224) describes this event:

... a rumor crossed the Atlantic that men were meeting at Niagara Falls, to try to arrange the terms of peace. Straightway men, instead of shaking hands and throwing up their hats in thankfulness...looked into each other's faces with blank despair, as if peace, instead of war, was the greatest curse upon earth. Nor was it without reason that this fear and terror was expressed. Middling Orleans cotton fell from thirty-one pence to twentythree pence halfpenny...men who held largely of cotton, twist, or cloth found their fortunes vanished in a night at the breath of this rumor. All trade arrangements were in chaos. The workers on full-time were reduced in two months by one hundred and forty-four thousand and fifty nine...

In a similar vein, the sharp fall in prices in the spring of 1865 was due to news that made it increasingly clear that the South could not win the war ${ }^{28}$ What this means for our purposes is that we can think of the timing of these two price declines as largely exogenous, and driven by the changing fortunes of the cotton textile industry. Thus, the responses observed in other sectors can be interpreted as the causal effects of the shock working through linkages to the cotton textile industry. In contrast to these events, the spike in bankruptcies in mid-1866 was driven by forces outside of the cotton textile sector, so this cannot be used to identify links between cotton textiles and other sectors of the economy ${ }^{29}$

I now turn to a regression approach that takes advantage of the exogenous shocks caused by the panics in late 1864 and early 1865. Because I am dealing with count data, I use Poisson regressions, specifically the Poisson Conditional Fixed Effects Maximum Likelihood Estimator (PCFE). The regression specification is,

\footnotetext{
${ }^{28}$ Watts (1866) writes, "In February, when it became evident that the Confederate government in America must die, the fall of Richmond renewed the panic in this country, and again the prices of cotton and cloth fell suddenly and considerably."

${ }^{29}$ Specifically, the panic in 1866 was precipitated by the failure of Overend, Gurney, \& Co., a "bankers bank" that played an important role in the British financial system at this time.
} 


$$
B K_{c t}^{i}=\phi_{c} \exp \left(\alpha^{i} \text { CotPanic } c t+\eta_{t}\right)
$$

where $B K_{c t}^{i}$ is the count of bankruptcies in industry $i$, city $c$ and month $t, \phi_{c}$ is a set of city fixed effects, CotPanic $c$ is an indicator variable for the cotton towns in Nov., 1864 and April, 1865 (the months after the cotton price drops generated a spike in cotton textile bankruptcies), and $\eta_{t}$ is a full set of time effects. Including these time effects allows me to control for economy-wide factors, such as changes in the interest rate, that may have affected the level of bankruptcies in an industry. This regression is run separately for each industry to obtain an industry-specific $\alpha^{i}$ describing whether each industry was impacted in the month after each of the panics.

The PCFE estimator has the advantage that it is robust to time dependent errors as long as the conditional mean is correctly specified (Bertanha \& Moser (2014)). Spatial dependence may be a concern, but Bertanha \& Moser (2014) show that as long as the pattern of spatial dependence is time invariant the standard sandwich PCFE estimator is consistent. My data pass Bertanha \& Moser's test for time-varying spatial dependence, so the results below use the standard sandwich estimator 30

The industry definitions used in these bankruptcy data follow those used in the cityindustry employment data built from the Census returns. However, because of sparseness in the data at the city-industry level, several of the smaller industries, those with few bankruptcies, have been aggregated 31

The results are shown in Table 9. Note that the number of observations used in each regression changes, as some industries show no bankruptcies in some towns over the period covered by these data, resulting in these towns being dropped. The first column of the top panel shows that bankruptcies increase in the cotton textile towns in the month following the panics. In particular, the incidence rate ratio for the arrival of a (non-cotton) bankruptcy in a cotton textile town during a panic period is 1.59. The remaining columns look at the response of particular industries in the month after the panics. While most industries show an increase, only two - "Merchants, agents, etc." and "Metal \& Machinery" - exhibit

\footnotetext{
${ }^{30}$ I have also explored results generated using the estimator introduced by Bertanha \& Moser (2014) that allows for time-varying spatial dependence. That approach generally leads to lower standard errors than those reported in Table 9 .

${ }^{31}$ Wool, linen/flax, and silk textiles have been aggregated into a single "Other textiles" category, while road, rail and sea \& canal transport have been aggregated into a single "Transport" category. "Messengers, warehousing, etc.", which includes warehousing, has been combined with the "Merchants, agents, etc" category. Two similar manufacturing industries, "Oils, soaps, etc." and "Chemicals \& drugs", have been combined. Several industries with too few bankruptcies have not been included in the analysis: "Earthenware \& bricks," "Shipbuilding," "Water \& gas service," and "Tobacco."
} 
statistically significant increases in bankruptcies. The first of these provides business services to the cotton textile industry. The second provides capital goods. The coefficient on the "Metal \& Machinery" result suggests an incidence rate ratio of 3.7, implying a substantial increase in bankruptcies in that industry in cotton textile towns in the month following each panic. Two categories, "Professionals" and "Mining related", show statistically significant reductions in bankruptcies in the month following a panic. However, these results are highly sensitive to the specification and should be considered unreliable. A variety of robustness check related to these results are presented in Appendix A.4. These show that the results for all non-cotton industries, for "Merchants, agents, etc.", and for "Metal \& Machinery" are robust to changes in the underlying data and the empirical approach.

Table 9: Bankruptcies by industry in the month following the cotton industry panics

\begin{tabular}{lccccc}
\hline \hline Industry: & $\begin{array}{c}\text { All except } \\
\text { cotton tex. }\end{array}$ & Agriculture & $\begin{array}{c}\text { Chemicals } \\
\text { \& oils }\end{array}$ & Construction & $\begin{array}{c}\text { Clothing } \\
\text { shoes, etc. }\end{array}$ \\
\hline CotPanic & $0.468^{* * *}$ & 0.315 & 0.327 & 0.157 & 0.717 \\
Obs. & $(0.169)$ & $(0.886)$ & $(0.571)$ & $(0.447)$ & $(0.665)$ \\
Towns & 3,402 & 2,520 & 2,142 & 3,318 & 3,066 \\
& 81 & 60 & 51 & 79 & 73 \\
\hline \hline Industry: & Drinks & Food & General & Instruments & Leather \\
& & processing & services & $\&$ jewelery & hair \\
\hline CotPanic & 0.321 & -0.550 & 0.343 & 0.665 & 0.659 \\
& $(0.624)$ & $(0.637)$ & $(0.565)$ & $(0.736)$ & $(0.683)$ \\
Obs. & 2,646 & 3,276 & 3,192 & 1,890 & 2,016 \\
Towns & 63 & 78 & 76 & 45 & 48 \\
& & & & & \\
\hline \hline Industry: & Merchant & Metal \& & Mining & Non-cotton & Paper \& \\
& agent, etc. & machinery & related & textiles & publishing \\
\hline CotPanic & $0.562^{*}$ & $1.305^{* * *}$ & $-16.10^{* * *}$ & 0.741 & 0.894 \\
& $(0.296)$ & $(0.323)$ & $(0.528)$ & $(0.650)$ & $(0.711)$ \\
Obs. & 2,856 & 3,192 & 2,184 & 1,260 & 2,226 \\
Towns & 68 & 76 & 52 & 30 & 53
\end{tabular}

\begin{tabular}{lccccc}
\hline \hline Industry: & Professionals & $\begin{array}{c}\text { Shopkeepers, } \\
\text { etc, }\end{array}$ & $\begin{array}{c}\text { Textile } \\
\text { finishing, etc. }\end{array}$ & Transport & $\begin{array}{c}\text { Wood \& } \\
\text { furniture }\end{array}$ \\
\hline CotPanic & $-12.73^{* * *}$ & 0.425 & 1.076 & 1.505 & -0.324 \\
& $(0.807)$ & $(0.419)$ & $(0.859)$ & $(1.080)$ & $(0.502)$ \\
Obs. & 2,604 & 3,360 & 1,680 & 2,058 & 2,478 \\
Towns & 62 & 80 & 40 & 49 & 59
\end{tabular}

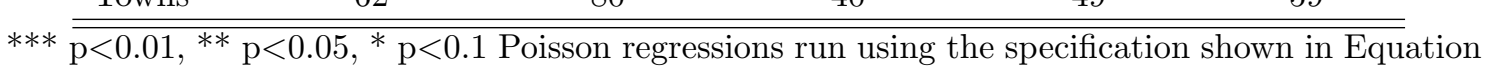
2 Robust standard errors shown in parenthesis. The data cover 59 towns from July, 1863 to December 1866. Some observations may be dropped from a regression because some industries show no bankruptcies in particular towns over the study period. 
The results above show that panic in the cotton textile sector spilled over into other industries, generating contemporaneous negative effects. In the next part of the analysis, I consider whether these contemporaneous impacts are also reflected in the long-run. To do so, I return to the Census of Population data. I start using data covering 1851-1871. The advantage of starting with this data set is that it allows me to analyze patterns occurring across 71 towns, with 8 cotton towns and 10 other textile towns.32 I apply a difference-indifference approach:

$$
\ln \left(E M P_{i c t+1}\right)-\ln \left(E M P_{i c t}\right)=\alpha+\sum_{i} a^{i}\left(\operatorname{CotTOWN} N_{c} * Y R_{1861-71}\right)+\eta_{i t}+\theta_{i c}+\epsilon_{i c t}
$$

where $E M P_{i c t}$ is employment in industry $i$, city $c$, and period $t, \operatorname{CotTOW} N_{c}$ is an indicator variable for towns with more than $10 \%$ of employment in cotton textiles in 1851, and $Y R_{1861-71}$ is an indicator variable for the 1861-1871 period, and $\eta_{i t}$ and $\theta_{i c}$ represent, respectively, a full set of industry-time and city-industry effects ${ }^{33}$ The $a^{i}$ coefficients in this regression allow me to identify the growth response of each industry in the cotton textile towns in the post-shock period, controlling for national industry growth and time-invariant city-industry growth rates.

Both serial and spatial correlation in errors are a potential concern in these regressions. To deal with these, I apply multi-dimensional clustered standard errors following Cameron et al. (2011) and Thompson (2011). Errors are clustered by city-industry to deal with serial correlation, by city-year, to allow correlated errors among industries within the same city, and by industry-year, to allow cross-city spatially correlated errors at the industry level.

Table 10 lists the estimated $a^{i}$ coefficients and standard errors. The first set of results are for a regression that includes all towns, while the second set are obtained when using only data from the 18 textile towns. A consistent result across both of these regressions is that the Metal \& Machinery industry experiences a significant reduction in employment growth in the 1861-1871 period in the cotton textile towns. Note that "Cotton textiles" does not exhibit negative impacts in the cotton textile towns relative to other cities in the data.

\footnotetext{
${ }^{32}$ Recall that cotton towns are those with more than $10 \%$ of their employment in cotton textiles. Other textile towns are those with more than $10 \%$ of their employment in textiles but less than $10 \%$ in cotton textiles. In general the share of cotton in these towns is low.

${ }^{33}$ Note that I could potentially include city-year effects here. These are not included because I want to allow for the possibility that many (perhaps all) industries grew more slowly in a particular city in a period, a possibility that would be eliminated if we control for overall city growth in a year.
} 
Table 10: Impact on industry growth in cotton towns, 1851-1871

\begin{tabular}{|c|c|c|c|c|}
\hline \multirow{2}{*}{ Industry } & \multicolumn{2}{|c|}{ All towns } & \multicolumn{2}{|c|}{ Only textile towns } \\
\hline & Coef & SE & Coef & SE \\
\hline Silk textiles & -0.6587 * & $(0.3615)$ & 0.0184 & $(0.4085)$ \\
\hline Tobacco & -0.5231 ** & $(0.2402)$ & -0.0445 & $(0.3030)$ \\
\hline Metal \& machinery & $-0.3036^{* \star \star}$ & $(0.1083)$ & $-0.5802 * \star *$ & $(0.1754)$ \\
\hline Mining related & -0.1695 & $(0.1163)$ & -0.0740 & $(0.1351)$ \\
\hline Textile finishing, etc. & -0.1673 & $(0.1748)$ & 0.2872 & $(0.2209)$ \\
\hline Earthenware, bricks, etc. & -0.1592 & $(0.1520)$ & -0.2973 & $(0.1850)$ \\
\hline Cotton textiles & -0.1066 & $(0.1982)$ & 0.2702 & $(0.2815)$ \\
\hline Professionals & -0.1024 & $(0.0637)$ & -0.2486 *** & $(0.0953)$ \\
\hline Wool textiles & -0.0413 & $(0.0976)$ & $-0.4129 * * *$ & $(0.1308)$ \\
\hline Paper \& publishing & -0.0341 & $(0.0621)$ & -0.0461 & $(0.0833)$ \\
\hline Construction & -0.0147 & $(0.0746)$ & -0.2318 ** & $(0.1137)$ \\
\hline Vehicles & -0.0130 & $(0.1436)$ & -0.2181 & $(0.1699)$ \\
\hline Drinks & 0.0266 & $(0.0396)$ & -0.0501 & $(0.0678)$ \\
\hline Clothing, dress \& shoe manuf. & $0.0619 * *$ & $(0.0310)$ & -0.0725 & $(0.0480)$ \\
\hline Wood \& furniture & 0.0852 & $(0.0619)$ & -0.0793 & $(0.0755)$ \\
\hline Chemicals \& drugs & 0.0924 & $(0.1313)$ & -0.2965 & $(0.2007)$ \\
\hline Instruments \& jewelry & 0.1291 & $(0.0986)$ & 0.2410 & $(0.2880)$ \\
\hline Drinks & 0.1299 & $(0.1396)$ & -0.0099 & $(0.1615)$ \\
\hline Road transport & 0.2063 & $(0.2999)$ & 0.1752 & $(0.3159)$ \\
\hline Messengers, warehousing, etc. & 0.2187 & $(0.1974)$ & -0.1917 & $(0.2159)$ \\
\hline Shipbuilding & 0.2268 & $(0.2028)$ & 0.3260 & $(0.3842)$ \\
\hline Water $\&$ gas service & $0.2332 * *$ & $(0.1051)$ & 0.2506 & $(0.1530)$ \\
\hline Sea \& canal transport & 0.2348 & $(0.2021)$ & 0.3044 & $(0.2640)$ \\
\hline Shopkeepers \& salesmen & $0.2374 * * \star x$ & $(0.0753)$ & 0.0328 & $(0.0973)$ \\
\hline Merchant, agents, etc. & 0.2427 ** & $(0.0942)$ & $0.2530 * *$ & $(0.1120)$ \\
\hline Leather \& hair goods & $0.2568 * * *$ & $(0.0771)$ & $0.3397 *$ & $(0.1921)$ \\
\hline Railway transport & $0.3834^{* \star \star}$ & $(0.1178)$ & 0.1203 & $(0.1295)$ \\
\hline Flax, linen, fustian & 0.4748 & $(0.3154)$ & -0.3535 & $(0.4459)$ \\
\hline Oils \& soaps manuf. & $0.5738^{* * \star}$ & $(0.1976)$ & 0.0447 & $(0.3499)$ \\
\hline
\end{tabular}

${ }^{* * *} \mathrm{p}<0.01,{ }^{* *} \mathrm{p}<0.05,{ }^{*} \mathrm{p}<0.1$. Table displays $a^{i}$ coefficients and standard errors based on the regression specification in Equation 3. The data cover 1851-1871. The first set of results use data on 71 towns with 2096 city-industries and 4161 observations. The second set of results use data on 18 textile towns with 534 city-industries and 1064 observations. In both sets, there are 8 cotton textile towns. The regressions include a full set of city-industry and industry-year effects. Standard errors, shown in parenthesis, are clustered by city-industry, city-year, and industry-year. The omitted industry is "General services."

Next, I use data covering the full 1851-1891 period and consider the effects on levels, rather than growth rates, to identify the industries that experienced persistent employment shifts in the cotton textile towns following the Civil War. The specification is,

$$
\ln \left(E M P_{i c t}\right)=a+\sum_{i}\left(b^{i} \operatorname{CotTOW} N_{c} * \operatorname{POST}_{t}\right)+\eta_{i t}+\theta_{i c}+\epsilon_{i c t}
$$


where $P O S T_{t}$ is an indicator variable for the decades after 1861.

Table 11 lists the estimated $b^{i}$ coefficients and standard errors for regressions based on Equation 4 with data from 1851-1891. The results in this table consistently show that the Metal \& Machinery sector suffered reduced employment in the decades after the Civil War shock. Construction, another capital-goods supplying industry also shows consistent negative effects. There is also evidence that some other textile industries, such as "Silk textiles," suffered reduced employment in the cotton textile towns. Results generated using more disaggregated data divided into 152 industry categories, available in Appendix A.5. show that among metal and machinery industries, the most negatively affected were pin and needle manufacturers and engine and machine makers. Both of these produced important capital inputs used by the textile industries ${ }^{34}$

One consistent result in Tables 9-11 is that the Metal \& Machinery sector suffered negative contemporaneous and long-term impacts in the cotton towns. This was an important sector in the British economy during this period 35 It was also a major employer in the six cotton textile towns studied in Table 11. Out of the 30 industries in the analysis database, Metal \& Machinery firms made up between 3.3 and 10.4 percent of employment in the cotton textile towns and were always among the 5 largest employers. In two towns, Bolton and Oldham, it was the second most important private-sector industry. Motivated by these facts, in the remainder of this section I take a closer look at the Metal \& Machinery industry.

Historical evidence suggests that the Metal \& Machinery sector had important ties to the cotton textile industry, ranging from textile machinery and tools to the steam engines that powered the textile factories ${ }^{36}$ There is also evidence that these producers gained from close proximity to their cotton textile customers. Textile machinery makers in Bolton, for example, specialized in producing machines for spinning fine thread counts, a product in which Bolton textile spinners were dominant, while in Oldham, machine makers specialized in machinery for spinning the coarser thread count products that were largely produced by textile factories in the Oldham area.

\footnotetext{
${ }^{34}$ The pin and needle manufacturers would have been important for producing components, such as cards, used in cotton textile machinery.

35 Allen (2009) (p. 273) writes that, "the great achievement of the British Industrial Revolution was, in fact, the creation of the first large engineering industry that could mass-produce productivity-raising machinery"

${ }^{36}$ Farnie (2004) writes that, "Textile engineering became the most important of all the ancillary trades [to cotton textile production]. Its light engineering section supplied spinning machines and looms and a while succession of related equipment, while its heavy engineering industry supplied steam engines, boilers, and mechanical stokers."
} 
Table 11: Long-run impact on industry growth in cotton towns, 1851-1891

\begin{tabular}{|c|c|c|c|c|}
\hline \multirow{2}{*}{ Industry } & \multicolumn{2}{|c|}{ All towns } & \multicolumn{2}{|c|}{ Only textile towns } \\
\hline & Coef & SE & Coef & SE \\
\hline Silk textiles & -1.0894 *** & $(0.2356)$ & -1.0130 *** & $(0.3204)$ \\
\hline Metal \& machinery & $-0.2692 * \star *$ & $(0.0783)$ & $-0.4599 * \star \star$ & $(0.1236)$ \\
\hline Wool textiles & -0.1620 & $(0.1078)$ & -0.1387 & $(0.1744)$ \\
\hline Shopkeepers \& salesmen & $-0.1513^{* *}$ & $(0.0705)$ & -0.1388 * & $(0.0839)$ \\
\hline Construction & $-0.1142 * \star \star *$ & $(0.0434)$ & $-0.2527^{\star \star *}$ & $(0.0856)$ \\
\hline Chemicals \& drugs & -0.1130 & $(0.1003)$ & $-0.4082 * *$ & $(0.1706)$ \\
\hline Messengers, warehousing, etc. & -0.0358 & $(0.1226)$ & -0.2790 * & $(0.1526)$ \\
\hline Tobacco & -0.0266 & $(0.1104)$ & -0.1389 & $(0.1916)$ \\
\hline Mining related & -0.0077 & $(0.1644)$ & -0.3529 & $(0.2737)$ \\
\hline Water $\&$ gas service & 0.0059 & $(0.0815)$ & -0.1691 & $(0.1243)$ \\
\hline Flax, linen, fustian & 0.0333 & $(0.4216)$ & -0.8392 & $(0.5268)$ \\
\hline Clothing, dress \& shoe manuf. & 0.0371 & $(0.0815)$ & -0.1398 & $(0.1022)$ \\
\hline Drinks & 0.0498 & $(0.1262)$ & -0.3400 ** & $(0.1367)$ \\
\hline Professionals & 0.0515 & $(0.0715)$ & -0.0581 & $(0.1005)$ \\
\hline Railway transport & 0.0543 & $(0.1443)$ & -0.0131 & $(0.1700)$ \\
\hline Food processing & 0.0575 & $(0.0557)$ & -0.1090 & $(0.0886)$ \\
\hline Road transport & 0.1164 & $(0.2392)$ & -0.1640 & $(0.2606)$ \\
\hline Earthenware, bricks, etc. & 0.1248 & $(0.1052)$ & -0.1541 & $(0.1866)$ \\
\hline Wood \& furniture & 0.1518 * & $(0.0846)$ & -0.0391 & $(0.0965)$ \\
\hline Paper \& publishing & 0.1539 * & $(0.0885)$ & 0.1039 & $(0.1175)$ \\
\hline Sea \& canal transport & 0.2169 & $(0.1746)$ & 0.1677 & $(0.2079)$ \\
\hline Leather \& hair goods & $0.2277 * *$ & $(0.1121)$ & -0.2161 ** & $(0.0986)$ \\
\hline Shipbuilding & 0.2327 & $(0.2054)$ & 0.2305 & $(0.2877)$ \\
\hline Merchant, agents, etc. & 0.2460 * & $(0.1310)$ & 0.0915 & $(0.1395)$ \\
\hline Vehicles & 0.2868 * & $(0.1551)$ & 0.1563 & $(0.1715)$ \\
\hline Textile finishing, etc. & 0.3004 * & $(0.1816)$ & -0.2843 & $(0.2299)$ \\
\hline Oils \& soaps manuf. & $0.3255^{* *}$ & $(0.1503)$ & 0.1490 & $(0.2564)$ \\
\hline Instruments \& jewelry & $0.3516^{\star \star \star \star}$ & $(0.1063)$ & 0.1025 & $(0.1150)$ \\
\hline Cotton textiles & $0.3780 * *$ & $(0.1842)$ & -0.0135 & $(0.3394)$ \\
\hline
\end{tabular}

${ }^{* * *} \mathrm{p}<0.01,{ }^{* *} \mathrm{p}<0.05,{ }^{*} \mathrm{p}<0.1$. Table displays $b^{i}$ coefficients and standard errors based on the regression specification in Equation 4. The data cover 1851-1891. The first set of results use data on 25 towns with 750 city-industries and 2987 observations. The second set of results use data on 12 textile towns with 360 city-industries and 1435 observations. In both sets, there are 6 cotton textile towns. The regressions include a full set of city-industry and industry-year effects. Standard errors, shown in parenthesis, are clustered by city-industry, city-year, and industry-year. The omitted industry is "General services."

Figure 12 describes the growth path of employment in the Metal \& Machinery industry in the cotton towns, the non-cotton textile towns, and all non-cotton towns, over the 18511891 period. Employment is given as the sum of log employment across the towns in each group, so that the larger towns do not dominate the results, and for comparability each 
series has been normalized by its 1851 value ${ }^{37}$ Prior to the Civil War, we can see that this industry was growing more rapidly in the cotton textile towns. After 1861, growth in the cotton textile towns slows down sharply, while growth in the non-cotton towns remains high (though slowing slightly during the weak economy of the 1870's). Overall, it appears that the Civil War period marked a relative decline of the growth of Metal \& Machinery employment in the cotton textile towns.

To summarize the results presented in this section, we can see that the shock to the cotton textile industry was transmitted to other industries in the cotton towns, particularly suppliers of capital goods. The negative impact of the shock on these industries played an important role in the reduced overall city growth rate in cotton textile towns. Figure 8 suggests that the fall in employment, particularly in the large Metal \& Machinery manufacturing industry, contributed as much to the reduction in city growth as the direct effect operating through the cotton textile industry.

Table 12: Employment in Metal \& Machinery industry by town type, 1851-1891

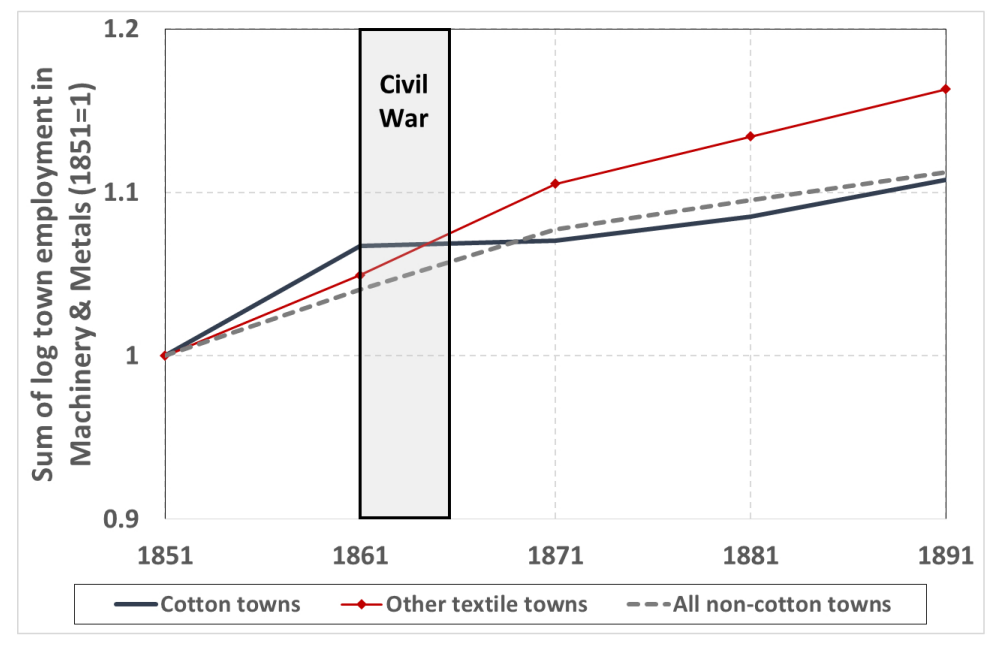

Figure displays the sum across log employment in each set of towns, normalized by the 1851 level. The data include the 25 towns for which consistent city-industry data are available from 1851-1891. There are 6 cotton textile towns and 6 non-cotton textile towns.

\section{Conclusions}

This paper draws on a unique historical setting in order to provide well-identified evidence on the persistent impacts of temporary sector-specific economic shocks to urban economies.

\footnotetext{
${ }^{37}$ Note that focusing on log employment is also consistent with my econometric approach.
} 
To my knowledge, this is the first study to trace out the persistent impacts of such shocks in a well-identified way. I find that the shock had a temporary effect on city population growth and a permanent impact on the level of city population. These levels effects are visible up to 35 years after the end of the temporary shock and show no sign of diminishing. This may have implications for urban policymakers, particularly when facing decisions related to the level of industrial diversity in a city.

My findings suggest that city growth may be characterized by multiple equilibrium growth paths. This result contrasts with previous studies, such as, (Davis \& Weinstein, 2002, 2008), which do not find persistent impacts on city size following a large negative shock. 38 It is not clear why my results differ from those obtained in previous work. This difference may be due to differences in the empirical setting, in particular because labor mobility was high and government intervention minimal in the British cities that I study. Alternatively, it may be due to differences in the type of shock considered, since I focus on an economic event while other studies have generally focused on war-related damage. Understanding why we observe persistent impacts in one setting but not in others is one direction for future research.

This is also the first study to provide well-identified evidence on the role of inter-industry connections in translating sector-specific shocks into aggregate effects. These inter-industry effects are important, explaining roughly half of the reduction in city employment growth during the Civil War period. This provides support for theoretical work in this area Gabaix (2011), Acemoglu et al. (2012)) and complements empirical results generated with more aggregated data (e.g., Foerster et al. (2011), Atalay (2014)). Additionally, this study provides new evidence on the channels that may be behind these results. While current studies tend to focus on all types of input-output connections, my findings suggest that connections to capital suppliers play a particularly important role. One explanation for this may be that capital investment was more procyclical than intermediate goods purchases, so that capital suppliers suffered more from the idiosyncratic shocks to their customers than intermediate suppliers. Another potential explanation is that capital producers may have been more reliant on local financing, which could have dried up during the crises. Further work is needed to differentiate between these and other potential channels. Finally, this study shows that these transmitted contemporaneous effects can also have long-run impacts, a point that has not been made in previous studies in this literature.

\footnotetext{
${ }^{38}$ Other studies, such as Bleakley \& Lin $(2012)$ and Redding et al. (2011) do find evidence of persistent effects. These studies both conder factors that were temporary but were in place for at least a couple of decades.
} 


\section{References}

Acemoglu, Daron, Carvalho, Vasco M., Ozdaglar, Asuman, \& Tahbaz-Salehi, Alireza. 2012. The Network Origins of Aggregate Fluctuations. Econometrica, 80(5), 1977-2016.

Allen, Robert C. 2009. The British Industrial Revolution in Global Perspective. Cambridge University Press. Altonji, Joseph, \& Card, David. 1991. The Effects of Immigration on the Labor Market Outcomes of LessSkilled Natives. In: Abowd, John M, \& Freeman, Richard B (eds), Immigration, Trade and the Labor Market. Chicago: University of Chicago Press.

Atalay, Enghin. 2014 (June). How Important are Sectoral Shocks? Working Paper.

Autor, David H., Dorn, David, Hanson, Gordon H., \& Song, Jae. 2012 (July). Trade Adjustment: Worker Level Evidence.

Autor, David H, Dorn, David, \& Hanson, Gordon H. 2013. The China Syndrome: Local Labor Market Effects of Import Competition in the United States. American Economic Review, 103(6), 2121-2168.

Bartel, Ann. 1989. Where Do the New US Immigrants Live? Journal of Labor Economics, 7, 371-391.

Bertanha, Marinho, \& Moser, Petra. 2014 (August). Spatial Errors in Count Data Regressions. NBER Working Paper No. 20374.

Bertrand, M, Duflo, E, \& Mullainathan, S. 2004. How Much Should We Trust Differences-in-Differences Estimates? The Quarterly Journal of Economics, 119(1), pp. 249-275.

Black, Dan, McKinnish, Terra, \& Sanders, Seth. 2005. The Economic Impact Of The Coal Boom And Bust. The Economic Journal, 115(503), 449-476.

Bleakley, Hoyt, \& Lin, Jeffrey. 2012. Portage: Path Dependence and Increasing Returns in U.S. History. Quarterly Journal of Economics, 127(May), 587-644.

Caballero, Ricardo J., \& Hammour, Mohamad L. 1994. The Cleansing Effect of Recessions. The American Economic Review, 84(5), pp. 1350-1368.

Cameron, A. C., Gelbach, J.B., \& Milller, D. L. 2011. Robust Inference with Multi-Way Clustering. Journal of Business and Economic Statistics, 29(2), 238-249.

Carrington, William J. 1996. The Alaskan Labor Market during the Pipeline Era. Journal of Political Economy, 104(1), pp. 186-218.

Conley, T.G. 1999. GMM estimation with cross sectional dependence. Journal of Econometrics, 92(1), 1 45.

Crafts, Nicholas, \& Wolf, Nikolaus. 2013 (August). The Location of the UK Cotton Textile Industry in 1838: a Quantitative Analysis. University of Warwick Working Paper.

Davis, Donald R, \& Weinstein, David E. 2002. Bones, bombs, and break points: The geography of economic activity. American Economic Review, 92(5), 1269-1289.

Davis, Donald R, \& Weinstein, David E. 2008. A search for multiple equilibria in urban industrial structure. Journal of Regional Science, 48(1), 29-65.

Dix-Carneiro, Rafael, \& Kovak, Brian. 2014 (July). Trade Reform and Regional Dynamics: Evidence from 25 Years of Brazilian Matched Employer-Employee Data. Working Paper.

Ellison, G., Glaeser, E., \& Kerr, W. 2010. What Causes Industry Agglomeration? Evidence from Coagglomeration Patterns. American Economic Review, 100(3), pp. 1195-1213.

Ellison, Glenn, \& Glaeser, Edward L. 1997. Geographic concentration in US manufacturing industries: A dartboard approach. Journal of Political Economy, 105(5), 889-927.

Farnie, D.A. 2004. The Role of the Cotton Industry in Economic Development. Oxford University Press. Chap. 18, pages pp. 557-584. 
Foerster, Andrew T., Sarte, Pierre-Daniel G., \& Watson, Mark W. 2011. Sectoral versus Aggregate Shocks: A Structural Factor Analysis of Industrial Production. Journal of Political Economy, 119(1), pp. 1-38. Gabaix, Xavier. 2011. The Granular Origins of Aggregate Fluctuations. Econometrica, 79(3), pp. $733-772$. Greenstone, Michael, Hornbeck, Richard, \& Moretti, Enrico. 2010. Identifying Agglomeration Spillovers: Evidence from Million Dollar Plants. Journal of Political Economy, 118(3), pp. 536-598.

Hanlon, W. Walker. Forthcoming. Necessity is the Mother of Invention: Input Supplies and Directed Technical Change. Econometrica.

Hanlon, W.W., \& Miscio, A. 2014 (March). Agglomeration: A Dynamic Approach. Mimeo.

Henderson, W.O. 1969. The Lancashire Cotton Famine 1861-1865. New York: Augustus M. Kelley Publishers.

Hornbeck, R. 2012. The Enduring Impact of the American Dust Bowl: Short- and Long-run Adjustments to Environmental Catastrophe. American Economic Review, 102(4), 1477-1507. Working paper.

Hsiang, Solomon M. 2010. Temperatures and cyclones strongly associated with economic production in the Caribbean and Central America. Proceedings of the National Academy of Sciences, 107(35), 15367-15372.

Kline, Patrick, \& Moretti, Enrico. 2013. Local Economic Development, Agglomeration Economies, and the Big Push: 100 Years of Evidence from the Tennessee Valley Authority. Quarterly Journal of Economics.

Kovak, Brian K. 2013. Regional Effects of Trade Reform: What is the Correct Measure of Liberalization? American Economic Review, 103(5), 1960-1976.

Lester, V. Markham. 1995. Victorian Insolvency: Bankruptcy, Improsonment for Debt, and Company Winding-up in Nineteenth-Century England. Oxford: Clare.

Miguel, Edward, \& Roland, Gerard. 2011. The Long Run Impact of Bombing Vietnam. Journal of Development Economics, 96(11954), 1-15.

Mitchell, B.R. 1988. British Historical Statistics. Cambridge, UK: Cambridge University Press.

Mitchell, BR, \& Deane, P. 1962. Abstract of British Historical Statistics. London: Cambridge University Press.

Newey, Whitney K., \& West, Kenneth D. 1987. A Simple, Positive Semi-Definite, Heteroskedasticity and Autocorrelation Consistent Covariance Matrix. Econometrica, 55(3), pp. 703-708.

Redding, Stephen J, Sturm, Daniel M, \& Wolf, Nikolaus. 2011. History and Industry Location: Evidence from German Airports. Review of Economics and Statistics, 93(3), 814-831.

Rosenthal, S., \& Strange, W. 2004. Handbook of Regional and Urban Economics. Elsevier. Chap. Evidence on the Nature and Sources of Agglomeration Economies.

Southall, HR, Gilbert, DR, \& Gregory, I. 1998 (Jan.). Great Britain Historical Database : Labour Markets Database, Poor Law Statistics, 1859-1939. [computer file]. UK Data Archive [distributor] SN: 3713.

Thomas, Mark. 1987. An Input-Output Approach to the British Economy, 1890-1914. Ph.D. thesis, Oxford University.

Thompson, Samuel B. 2011. Simple formulas for standard errors that cluster by both firm and time. Journal of Financial Economics, 99(1), 1 - 10.

Topalova, Petia. 2007. Trade Liberalization, Poverty and Inequality: Evidence from Indian Districts. University of Chicago Press. Chap. Globalization and Poverty, pages 291-336.

Topalova, Petia. 2010. Factor Immobility and Regional Impacts of Trade Liberalization: Evidence on Poverty from India. American Economic Journal: Applied Economics, 2(4), 1 - 41.

Watts, John. 1866. The Facts of the Cotton Famine. London: Simpkin, Marshall, \& Co. 


\section{A Appendix}

\section{A.1 Empirical setting appendix}

This section provides additional details and charts describing the empirical setting. Figure 6 shows import and export data for Britain during the Civil War period, where imports and exports related to textiles have been separated from those related to all other industries.

Figure 6: British imports and exports 1851-1869

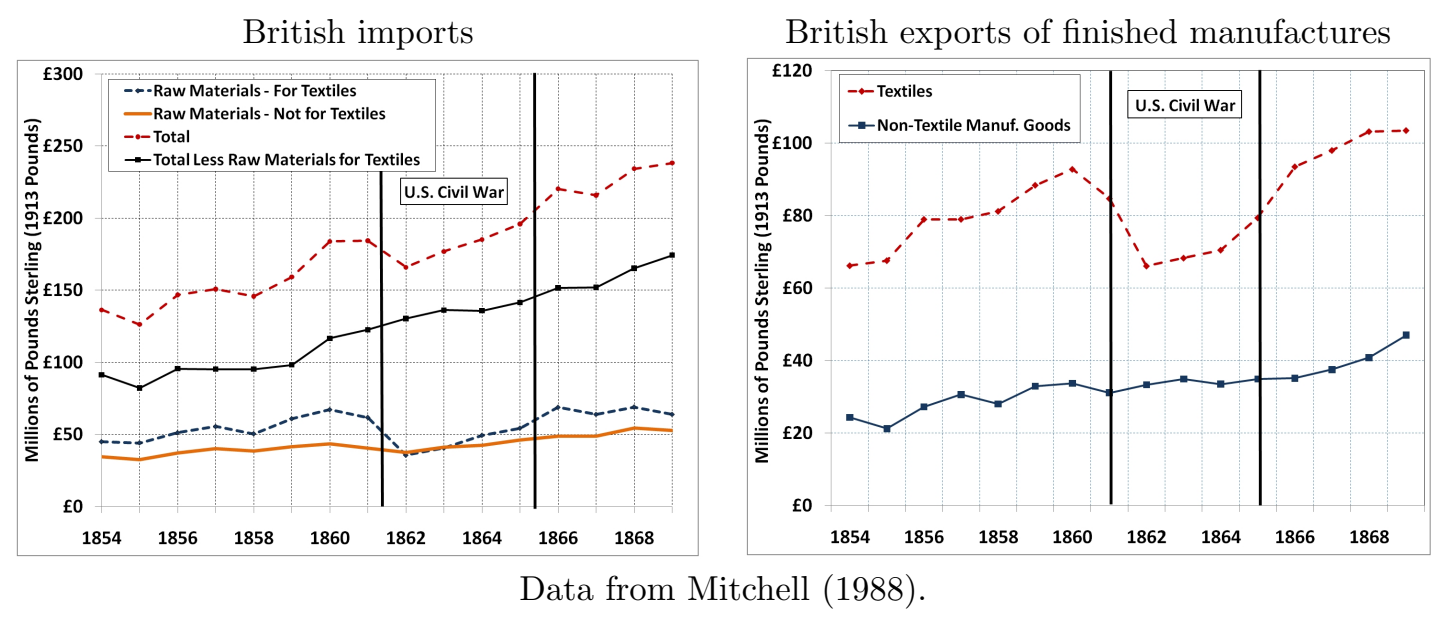

Figure 7 shows employment in the four main textile sectors over the 1851-1891 period based on Census of Population data available every ten years starting in 1851. The cotton textile industry grew rapidly from 1851-1861, but growth slowed from 1861-1871. In contrast, wool textiles experienced a growth acceleration during the 1861-1871 period, due largely to the lack of competition from cotton textiles. All of the textile industries experienced slow growth from 1871-1881, a period that includes the Long Depression of 1873-1879. Over all periods, cotton textiles did substantially better than the declining silk and flax/linen sectors. 
Figure 7: Employment in cotton, wool, linen, and silk textile industries, 1851-1891

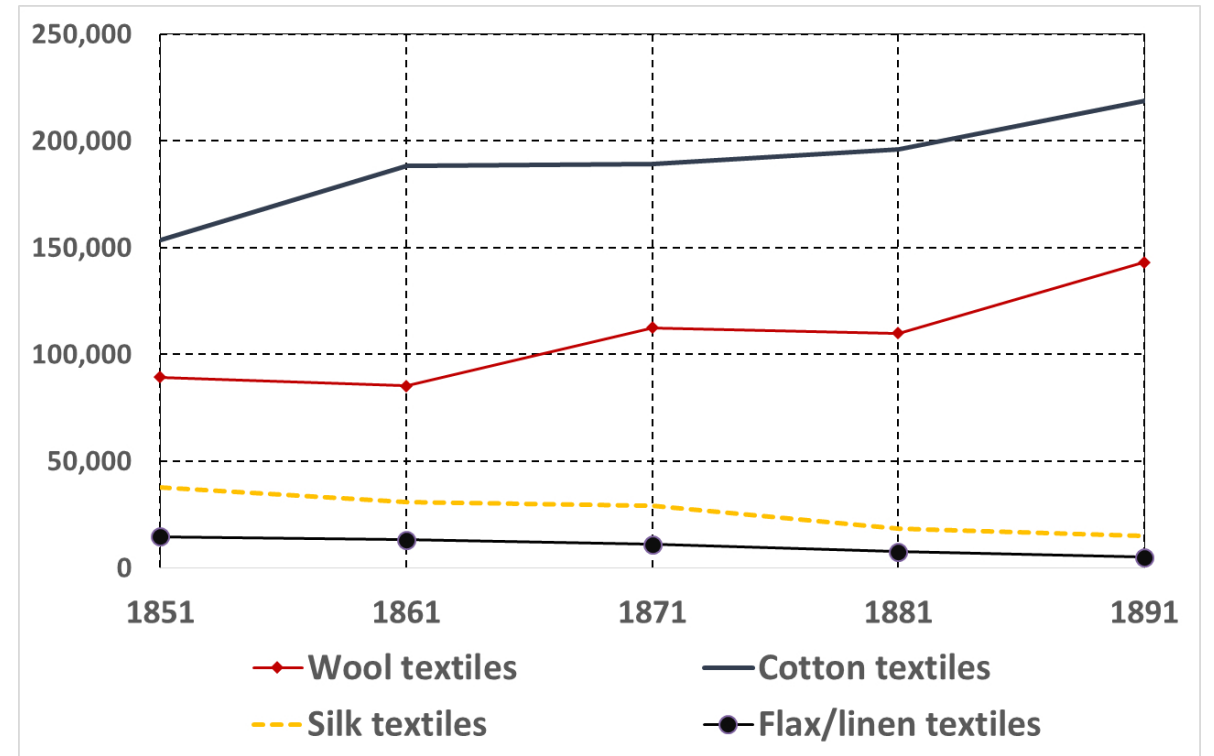

Chart includes data from the 25 towns for which city-industry data are available over the 1851-1891 period (see Data section for details).

Figure 8 provides some additional data that allows us to construct a rough proxy for the pattern of productivity growth in the cotton textile industry over the study period. The solid line describes national cotton textile employment over the study period (in a log scale). We can see that the pattern of national employment growth matches the pattern shown in Figure 7 for the 25 towns contained in the main city-industry database. The top line in Figure 8 gives cotton consumption in the year before each employment observation based on data from Mitchell \& Deane (1962). I.e., for 1851 I report cotton consumption in 1850. This is done both because the Census employment data come from early in the year and because it allows me to report consumption in 1860 rather than 1861, when consumption was impacted by the beginning of the Civil War. This is the best available measure of industry output. Finally, the dashed line in the middle of the graph reports cotton consumption, in thousands of pounds, per cotton textile worker. This provides a rough proxy for productivity growth in the industry. We can see that productivity grew strongly between 1851 and 1861, stagnated from 1861-1871, and then resumed growing at a somewhat slower pace. This pattern may seem surprising given that Hanlon (Forthcoming) shows that there was a burst in innovative activity in the cotton textile industry during the Civil War period. However, the innovation undertaken during the Civil War period was primarily aimed at mitigating the negative productivity effect of switching from higher-quality U.S. cotton to 
lower quality cotton coming primarily from India. Thus, innovation during the Civil War period served mainly to reduce the negative productivity effects of the war, rather than to increase productivity relative to the pre-war period.

Figure 8: Cotton textile employment, consumption, and consumption per worker, 1851-1891

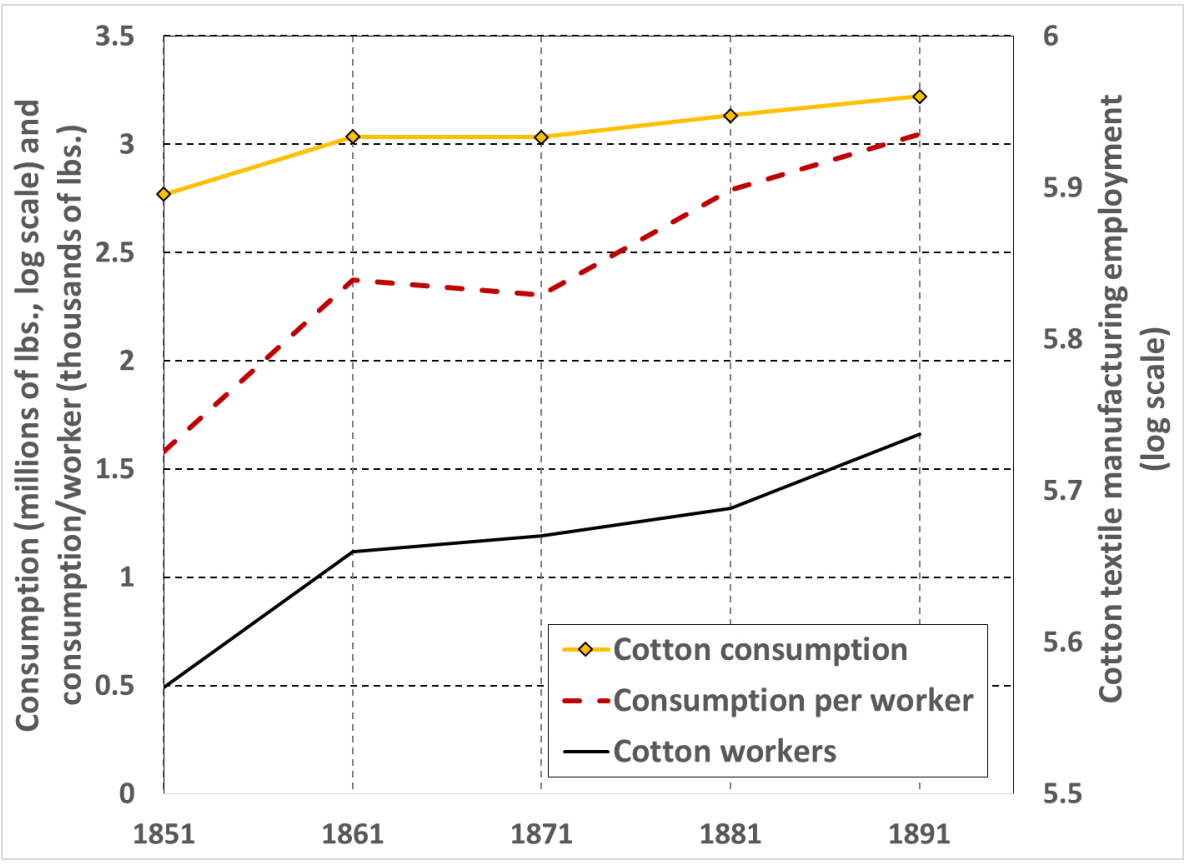

Total cotton textile employment for England and Wales is based on Census data. Cotton consumption data, from Mitchell \& Deane (1962), are for the year before the employment observation.

Figure 9 compares the agglomeration patterns of the textile industries over the study period using the index from Ellison \& Glaeser (1997) and firm size data from the 1907 Census of Production. Somewhat surprisingly, cotton textile was actually less agglomerated than the other textile industries during the study period. This was due in part to the fact that the industry was so large that it was forced to spread over numerous towns, while smaller textile industries were easier to accommodate in just one or a few towns. Another pattern visible in the data is that after 1861 the cotton textile industry became more agglomerated, while the level of agglomeration tended to decline in all of the other textile industries over the study period. 
Figure 9: Geographic agglomeration in the textile industries over time

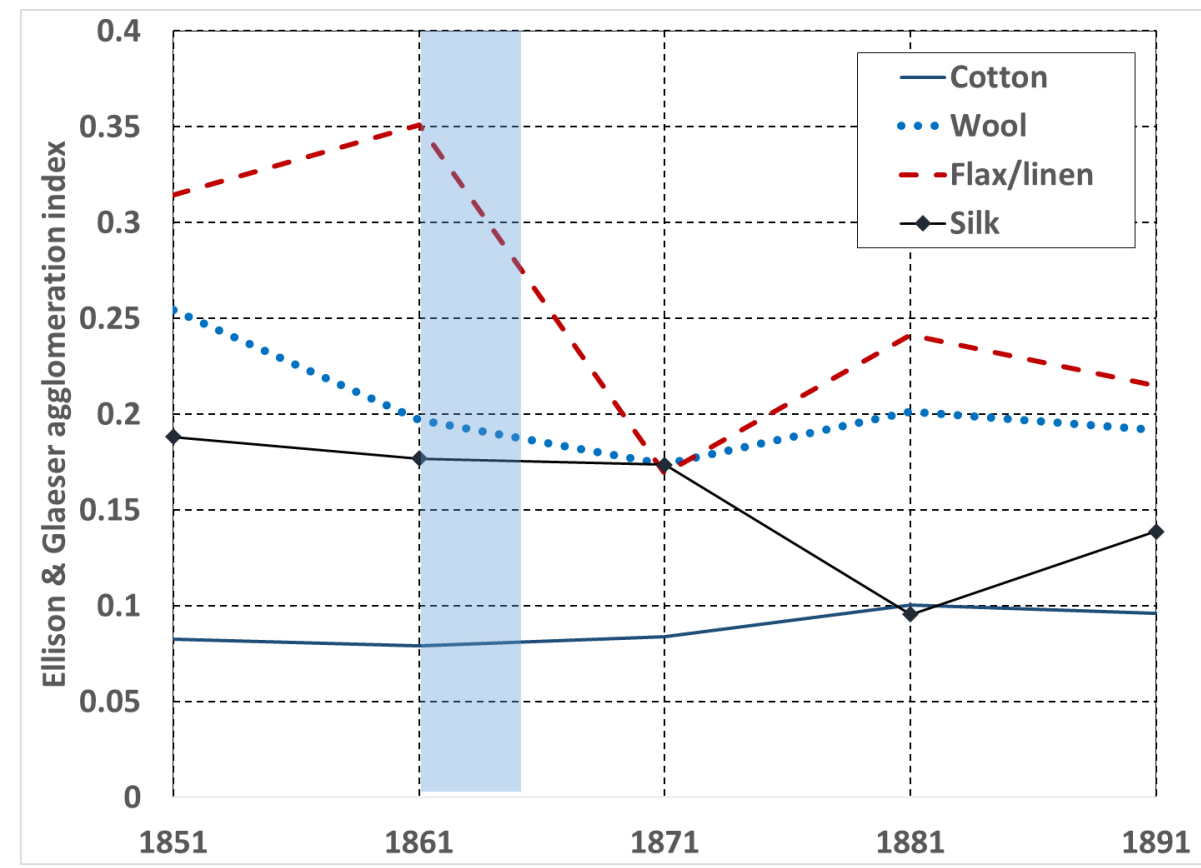

Agglomeration in the textile industries calculated using the index from Ellison \& Glaeser (1997) and firm size data from the 1907 Census of Production. Calculations use 24 of the 25 towns included in the city-industry database, with London excluded.

\section{A.2 Data appendix}

This section presents some additional details about the data used in this study. For the Census of Population employment data, extensive details are available in the online appendix to Hanlon \& Miscio (2014). ${ }^{39}$ Thus, this appendix focuses on the bankruptcy data, which are unique to this paper.

The data on bankruptcies come from the London Gazette and were collected starting in Nov. 15, 1861, when they Gazette begins reporting bankruptcies filed under the new Bankruptcy Act of 1861. To obtain the data, PDFs were downloaded from the London Gazette website, and then the information was hand-entered off of each sheet. I have collected only information from the "Notice of Adjudication of Bankruptcy and First Meeting of Creditors." These notices, which informed creditors that a person had filed for bankruptcy, represented the first posted notice following a bankruptcy filing. They usually come within the week after the bankruptcy judgment.

\footnotetext{
${ }^{39}$ See www.econ.ucla.edu/whanlon/papers/hanlon_miscio_data_appendix.pdf.
} 
Figure 10 shows the first notice entered into the database. From each notice, we entered the name of the bankrupt, their occupation, and their town and county. London counts as both a town and a county. The occupation data was then hand cleaned and standardized. In doing so, I tried to follow as closely as possible the categorizations used in the Census occupation data.

Figure 10: Example bankruptcy notice from the London Gazette, Nov. 15, 1861

The Bankruptcy Act, 1861.

Notice of Adjudications and First Meeting of Creditors.

\begin{abstract}
James White, of Dunstable, in the county of Bedford, Bulder and Brickiager, having been adjudged bankrupt under a Petition for adjudication of Bankruptcy, filed in Her Majesty's Court of Bankruptey, in London, on the 9tb dny of Norember, 1861, is hereby required to surrender himself to Theophilus Bennet Hoskyns A brahall, Esq., a Registrar of the said Court, at the first meeting of creditors to be held before the said Registrar, on the 27th day of November instant, at eleven o'clock in afternorn precisely, as the said Court. Mr. William Bell, of No, 3, Coleman. street-buildings, is the Official Assignee, and Messrs. Hurrison and Lewis, of No. 6, Old Jewry, are the Solicitors acting in the bankruptey.
\end{abstract}

In many cases the notices list multiple occupations; I focus on the first occupation listed (a similar approach was taken by the Census office when constructing the Census data categories). Table 13 lists the number of bankruptcies in each of the industry categories in England and Wales over the period from Nov. 151861 to the end of 1866. The largest category of bankruptcies is among shopkeepers and salesman, followed by construction, food processing (bakers, butchers, etc.), and merchants, agents and accountants (which includes all commercial businessmen). Among manufacturing categories, we can see that the largest number of bankruptcies occurred among clothing and shoe producers. This makes sense given that this sector was characterized by many small local producers. There is also a large number of bankruptcies in the metal and machinery category, which is characterized by a mix between large and small firms. The number of bankruptcies in textile manufacturing are relatively small, reflecting the fact that firms in that sector were larger. 
Table 13: Bankruptcy counts by industry category, Nov. 1861 - Dec. 1866

\begin{tabular}{lrlr}
\hline Industry & Bankruptcies & Industry & Bankruptcies \\
\hline Agriculture & 2,159 & Misc. textiles & 598 \\
Chemicals \& drugs & 415 & Oil, soap, etc. & 248 \\
Construction & 3,915 & Other misc. industries & 939 \\
Cotton textiles & 277 & Paper \& publishing & 715 \\
Clothing, shoes, etc. & 2,727 & Professionals & 1,479 \\
Drinks & 1,043 & Railway transport & 108 \\
Earthenware \& bricks & 391 & Road transport & 582 \\
Flax/linen textiles & 106 & Sea \& canal transport & 311 \\
Food processing & 3,762 & Shipbuilding & 121 \\
General services & 2,282 & Shopkeepers, etc. & 5,765 \\
Government workers & 471 & Silk textiles & 86 \\
Instruments \& jewelery & 643 & Tobacco & 197 \\
Leather, hair, etc. & 675 & Unemployed & 1,070 \\
Merchants, agents, etc. & 2,983 & Unknown/unclassified & 1,607 \\
Messengers, warehousing, etc. & 282 & Water \& gas workers & 95 \\
Metal \& machinery & 2,225 & Wood \& furniture & 938 \\
Mining related & 641 & Wool textiles & 243 \\
\hline
\end{tabular}

The bankruptcy law in England underwent a major change with the passing of the Bankruptcy Act of 1861. This Act merged bankruptcy and insolvency law (Lester (1995)). Prior to the Act, only "traders" could file for bankruptcy, which allowed them to discharge their debts without fear of imprisonment. The Act extended these bankruptcy protections to all. This had the result of substantially increasing the number of bankruptcies, particularly during the first year after the law change. This pattern is clearly visible in Figure 11 , which plots the number of bankruptcies by month in England and Wales from Nov. 15, 1961 through 1866. These data begin in the middle of November of 1861 because that was the first point at which the London Gazette begins reporting notices of preliminary adjudication of bankruptcy under the new 1861 law.

To avoid the large spike in bankruptcies caused by the change in bankruptcy laws, I begin my analysis with data starting in July of 1863 . Thus, my analysis excludes the months highlighted in Figure 11. This Figure suggests that by mid-1863 the initial surge of bankruptcies had passed and the overall level of bankruptcies had reached something resembling a normal level. 
Figure 11: Monthly bankruptcy counts, Nov. 1861 - Dec. 1866

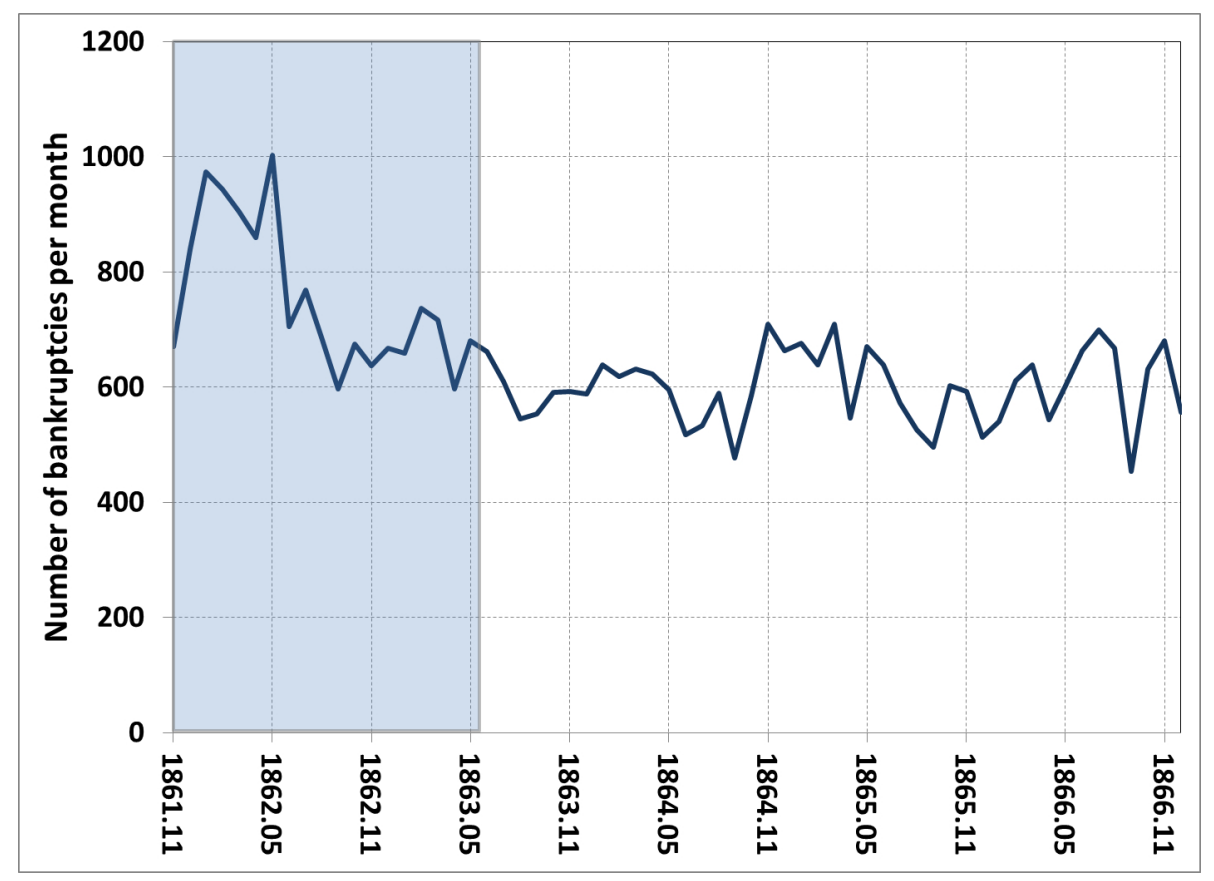

Excluding data prior to July, 1863 leaves me with 25,123 bankruptcies. Because this cutoff is somewhat arbitrary, I check the robustness of the results to the alternative of using all of the data from 1863 (see Section A.4). Next, I limit the data geographically to ensure that I am comparing the cotton textile towns to other urban areas. Specifically, I limit the set of analysis towns to those in which a reasonable number (at least 30) bankruptcies occurred of the period from mid-1863 through 1866. Table 14 shows the set of towns with more than 30 bankruptcies. I also exclude London from the main analysis. This is done both because London is an outlier in terms of size, and because the data from London are more difficult to deal with. This is because within London, people often listed their location as their neighborhood, rather than simply as London. Also, in many areas that were part of the city of London, people sometimes reported them as part of one of the home counties, particularly Middlesex. As a result, it is necessary to include all of Middlesex as part of London. The robustness exercises in Section A.4 show that including London does not substantially affect my findings. 
Table 14: Towns included in the bankruptcy analysis

\begin{tabular}{|c|c|c|c|c|c|}
\hline Town & County & Bankruptcies & Town & County & Bankruptcies \\
\hline London & London & 7607 & West Bromwich & Staffordshire & 49 \\
\hline Liverpool & Lancashire & 880 & Carlisle & Cumbria & 48 \\
\hline Manchester* & Lancashire & 708 & Cambridge & Cambridgeshire & 46 \\
\hline Birmingham & Warwickshire & 697 & Shrewsbury & Salopshire & 45 \\
\hline Leeds ** & Yorkshire & 334 & Yarmouth & Norfolk & 43 \\
\hline Stoke-on-Trent & Staffordshire & 280 & Walsall & Staffordshire & 43 \\
\hline Sheffield & Yorkshire & 270 & Kingswinford & Staffordshire & 43 \\
\hline Bristol & Gloucestershire & 257 & Stockton-on-Tees & Durham & 42 \\
\hline Bradford ** & Yorkshire & 187 & Burnley * & Lancashire & 42 \\
\hline Brighton & Sussex & 175 & Bolton * & Lancashire & 42 \\
\hline Hull & Yorkshire & 171 & Worcester & Worcestershire & 42 \\
\hline Portsmouth & Hampshire & 164 & Chatham & Kent & 41 \\
\hline Wolverhampton & Staffordshire & 148 & Maidstone & Kent & 40 \\
\hline Norwich ** & Norfolk & 144 & Canterbury & Kent & 40 \\
\hline Nottingham ** & Nottinghamshire & 141 & Dewsbury ** & Yorkshire & 40 \\
\hline Newcastle & Northumberland & 132 & Stratford & Essex & 39 \\
\hline Leicester & Leicestershire & 118 & Gloucester & Gloucestershire & 39 \\
\hline Southampton & Hampshire & 110 & Gravesend & Kent & 38 \\
\hline Halifax ** & Yorkshire & 105 & Wednesbury & Staffordshire & 38 \\
\hline Plymouth & Devon & 100 & Bilston & Staffordshire & 37 \\
\hline Huddersfield ** & Yorkshire & 90 & Scarborough & Yorkshire & 37 \\
\hline Derby ** & Derby & 83 & Ashton * & Lancashire & 36 \\
\hline Chorlton & Lancashire & 83 & Grimsby & Lincolnshire & 36 \\
\hline Northampton & Northamptonshir $\epsilon$ & 79 & Tipton & Staffordshire & 36 \\
\hline Birkenhead & Cheshire & 76 & Aston & Warwickshire & 35 \\
\hline Exeter & Devon & 74 & Middlesbrough & Yorkshire & 35 \\
\hline Oldham * & Lancashire & 74 & Warrington * & Lancashire & 34 \\
\hline Lincoln & Lincolnshire & 74 & Reading & Berkshire & 33 \\
\hline Sunderland & Durham & 72 & Macclesfield & Cheshire & 33 \\
\hline Dudley & Worcestershire & 71 & Bury * & Lancashire & 33 \\
\hline Ipswich & Suffolk & 69 & York & Yorkshire & 33 \\
\hline Cheltenham & Gloucestershire & 68 & Bedford & Bedfordshire & 32 \\
\hline Blackburn * & Lancashire & 66 & South Shields & Durham & 32 \\
\hline Chester * & Cheshire & 64 & Tonbridge Wells & Kent & 32 \\
\hline Bath & Somerset & 63 & Newark & Nottinghamshire & 32 \\
\hline Hastings & Sussex & 63 & Kidderminster & Worcestershire & 32 \\
\hline Rochdale * & Lancashire & 61 & Stockport * & Cheshire & 31 \\
\hline Hereford & Herefordshire & 59 & Winchester & Hampshire & 30 \\
\hline Coventry ** & Warwickshire & 53 & Aldershot & Hampshire & 30 \\
\hline Oxford & Oxfordshire & 52 & Wigan * & Lancashire & 30 \\
\hline Wakefield ** & Yorkshire & 52 & & & \\
\hline Luton & Bedfordshire & 49 & & & \\
\hline
\end{tabular}

* indicates cotton towns. ${ }^{* *}$ indicates other textile towns.

An important feature of the bankruptcy data set is that it covers all private bankruptcies. Thus, it may include both bankruptcies by the owners of private business and bankruptcies by workers who do not own a business. In some cases, the occupation data allow us to identify whether the person works for a business or is a business owner, but in general it is not 
possible to systematically separate these two types of bankruptcies. This is not necessarily a drawback of the data; even bankruptcies by individuals that were not business owners can be revealing, since individuals are more likely to file for bankruptcy when they become unemployed, which in turn is often a reflection of the distress of their former employer. In one respect this may offer a type of quality adjustment, since bankruptcies by larger firms are more likely to result in bankruptcies by their workers. Still, we may be concerned that including bankruptcies by workers is misleading. To try to help address this issue, I have categorized bankruptcies where the individual is obviously a worker rather than a business owner. These are identified as occupations in which the bankrupt is listed as an "Assistant", "Journeyman", "Servant", "Labourer", "Foreman", "Manager", "Machinist", "Engineer" (which at this time often means someone who operates an engine), and "Clerk." In the robustness exercises in Section A.4, I show that my main results are unchanged when bankruptcies containing one of these worker identifiers are dropped.

For manufacturing industries, I have classified both makers and dealers into the same category, a practice which follows the system used in the Census data. Thus, both a machine manufacturer and a machine parts dealer would be listed in the Metal \& Machinery category. However, much of the existing literature in this area has focused on manufacturers and excluded dealers. To enable a similar divide in my data, I reviewed every occupation in the manufacturing categories and divided them into "Makers" and "Dealers". Many occupations include both producing and selling a good, and these I have classified as Makers. In the robustness exercises in Section A.4. I calculate separate results for the manufacturing industries in which dealers are dropped from the data. I find that focusing exclusively on makers does not affect the results in a substantial way.

Another issue arises for public companies. Bankruptcies of public companies will not be reflected in the bankruptcy database. However, public companies were a rarity during the period I study; the vast majority of companies would have been privately held and therefore would appear in the bankruptcy data.

\section{A.3 Further evidence on migration flows}

To explore the factors that determined migration flows out of the Northwest, I use town-level data on the location of birth of town residents from 1851-1871. The specification is,

$$
\Delta \log \left(\text { NWborn }_{c t}\right)=\alpha_{0}+\alpha_{1}\left(X_{1851} * \text { Shock }_{t}\right)+\alpha_{2} \Delta \log \left(\text { NOTNWborn }_{c t}\right)+\delta_{c}+\eta_{t}+e_{c t}
$$


where $\Delta \log \left(N\right.$ Wborn $\left._{c t}\right)$ represents the growth rate of Northwest-born residents in city $c$ and decade $t, \Delta \log \left(N O T N W\right.$ born $\left._{c t}\right)$ is the growth rate of residents not born in the Northwest, $X_{i}^{1851}$ is some town feature in 1851, Shock $k_{t}$ is an indicator variable for the decade of the Civil War, $\delta_{c}$ is a full set of city fixed effects, and $\eta_{t}$ is a time effect. Thus, the coefficient $\alpha_{1}$ identifies the features of towns that experienced an acceleration in the growth of their Northwest-born population during the Civil War period, while controlling for differences in the overall growth rate of the town population born outside of the Northwest counties.

The data allow me to explore several potential drivers of migration flows. First, I look at measures of the economic similarity and geographic proximity of towns, as described above. I also consider a town's initial share of residents born in the Northwest, since ties to previous migrants has been shown to be an important determinant of later migration flows (Bartel (1989), Altonji \& Card (1991)). I also consider the share of cotton textiles, wool textiles, or manufacturing in total employment. I control for the growth rate of town residents born outside of the Northwestern counties to account for the fact that migrants are likely to be attracted to more rapidly growing towns.

The results are shown in Table A.3. The separated regression in Columns 1-5 suggest that three factors - geographic proximity, the initial population of Northwest residents in a town, and the share of wool textiles in town employment - may have played a role in determining migration patterns. However, once all factors are combined in Columns 6-7, only geographic proximity remains statistically significant. Not surprisingly, city growth also plays a strong role in attracting migrants. Once we control for each city's growth rate, geographic proximity is the key determinant of migration patterns. 
Table 15: Factors affecting migration flows of Northwest-born population during the Civil War

\begin{tabular}{|c|c|c|c|c|c|c|c|}
\hline \multicolumn{8}{|c|}{ DV: Decadal growth in Northwest-born residents } \\
\hline & (1) & (2) & (3) & (4) & (5) & (6) & (7) \\
\hline $\begin{array}{l}\text { Geographic proximity } \\
\text { * Shock }\end{array}$ & $\begin{array}{c}3.061^{* *} \\
(1.302)\end{array}$ & & & & & $\begin{array}{l}3.338^{* *} \\
(1.579)\end{array}$ & $\begin{array}{l}3.799^{* *} \\
(1.616)\end{array}$ \\
\hline $\begin{array}{l}\text { Economic similarity } \\
* \text { Shock }\end{array}$ & & $\begin{array}{c}0.330 \\
(0.228)\end{array}$ & & & & $\begin{array}{l}-0.103 \\
(0.271)\end{array}$ & \\
\hline $\begin{array}{l}\text { Initial NW pop. } \\
* \text { Shock }\end{array}$ & & & $\begin{array}{l}16.34^{*} \\
(9.579)\end{array}$ & & & $\begin{array}{l}-0.965 \\
(10.84)\end{array}$ & $\begin{array}{l}-7.764 \\
(14.43)\end{array}$ \\
\hline $\begin{array}{l}\text { Cotton emp. shr. } \\
* \text { Shock }\end{array}$ & & & & $\begin{array}{c}3.023 \\
(4.939)\end{array}$ & & & $\begin{array}{l}-0.647 \\
(4.966)\end{array}$ \\
\hline $\begin{array}{l}\text { Wool emp. shr. } \\
\text { * Shock }\end{array}$ & & & & $\begin{array}{l}0.988^{*} \\
(0.583)\end{array}$ & & & $\begin{array}{l}0.749 \\
(1.107)\end{array}$ \\
\hline $\begin{array}{l}\text { Non-textile manuf. } \\
\text { emp. shr. } * \text { Shock }\end{array}$ & & & & & $\begin{array}{c}0.834 \\
(0.515)\end{array}$ & & $\begin{array}{l}-0.377 \\
(0.570)\end{array}$ \\
\hline $\begin{array}{l}\text { Growth of pop. } \\
\text { non-NW-born }\end{array}$ & $\begin{array}{l}1.100^{* *} \\
(0.452)\end{array}$ & $\begin{array}{l}1.354^{* *} \\
(0.616)\end{array}$ & $\begin{array}{c}1.227^{* *} \\
(0.597)\end{array}$ & $\begin{array}{l}1.245^{*} \\
(0.709)\end{array}$ & $\begin{array}{l}1.399^{* *} \\
(0.574)\end{array}$ & $\begin{array}{l}1.126^{* *} \\
(0.469)\end{array}$ & $\begin{array}{l}1.030^{*} \\
(0.534)\end{array}$ \\
\hline Constant & $\begin{array}{l}0.175^{* *} \\
(0.0744)\end{array}$ & $\begin{array}{c}0.142 \\
(0.0933)\end{array}$ & $\begin{array}{c}0.158^{*} \\
(0.0927)\end{array}$ & $\begin{array}{c}0.156 \\
(0.104)\end{array}$ & $\begin{array}{c}0.136 \\
(0.0894)\end{array}$ & $\begin{array}{l}0.172^{* *} \\
(0.0757)\end{array}$ & $\begin{array}{l}0.184^{* *} \\
(0.0792)\end{array}$ \\
\hline Observations & 98 & 98 & 98 & 98 & 98 & 98 & 98 \\
\hline R-squared & 0.305 & 0.220 & 0.244 & 0.222 & 0.229 & 0.306 & 0.311 \\
\hline Number of towns & 49 & 49 & 49 & 49 & 49 & 49 & 49 \\
\hline
\end{tabular}

Robust standard errors in parenthesis. Data cover 49 towns from 1851-1871. All regressions include a full set of city fixed effects and decade effects. "Shock" is an indicator variable for the 1861-1871 period. Geographic proximity is measured as exp (-dist) where dist is the distance in thousands of km to Manchester. Economic proximity is measured by taking the correlation in the vector of employment shares in a set of broad employment sectors between each town and the average employment shares across the cotton textile towns in 1851. Initial NW pop. is the share of NW-born residents in total town population in 1851. Cotton emp. shr. is the share of cotton textile workers in total town employment in 1851. Wool emp. shr. is the share of wool textile workers in total town employment in 1851. Non-textile manuf. emp. shr. is the share of all other manufacturing workers in total town employment in 1851.

\section{A.4 Additional bankruptcy results}

This section provides some additional details related the the analysis of the bankruptcy data. First, I provide additional charts, similar to Figure 5, describing the pattern of bankruptcies in sectors unrelated to cotton textiles in the Northwest counties, in sectors related to cotton 
textiles in the wool towns, and in sectors related to cotton textiles in all non-cotton towns. Following that, I present a series of robustness checks related the results presented in Table 9.

Figure 12: Bankruptcies in other sectors in major cotton textile towns

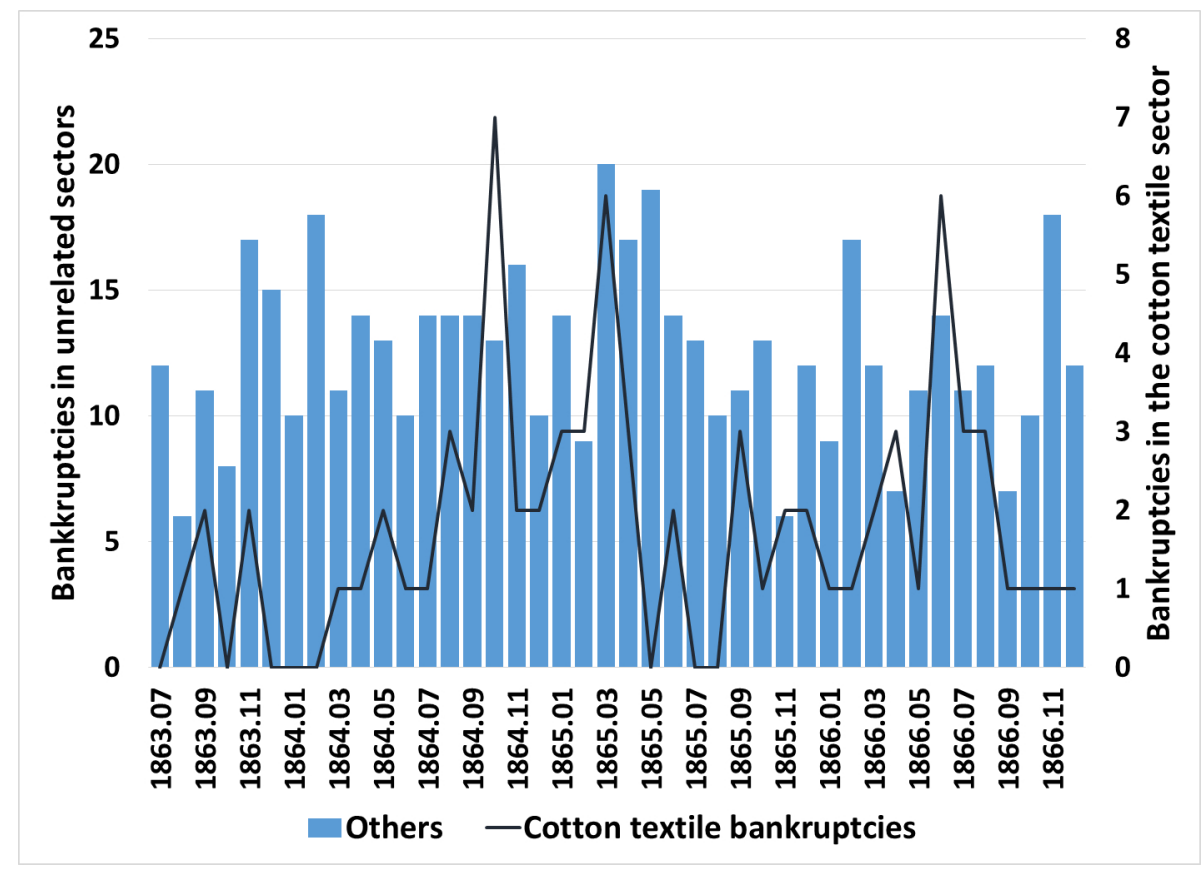

Bankruptcy data were collected from the London Gazette. The bar chart (left-hand axis) describes bankruptcies in those sectors not included in Figure 5. These include many shopkeepers, beer sellers, government employees, farming and mining firms, and some other miscellaneous occupations. Solid line (right-hand axis) describes the number of bankruptcies in the cotton textile sector. The cotton textile towns included in this chart are Accrington, Ashton-under-Lyne, Blackburn, Bolton, Burnley, Bury, Manchester, Oldham, Preston, Rochdale, Warrington, Wigan, Stockport and Chester. All of these are in Lancashire except for the last two, which are in Cheshire. 
Figure 13: Bankruptcies in major wool textile towns

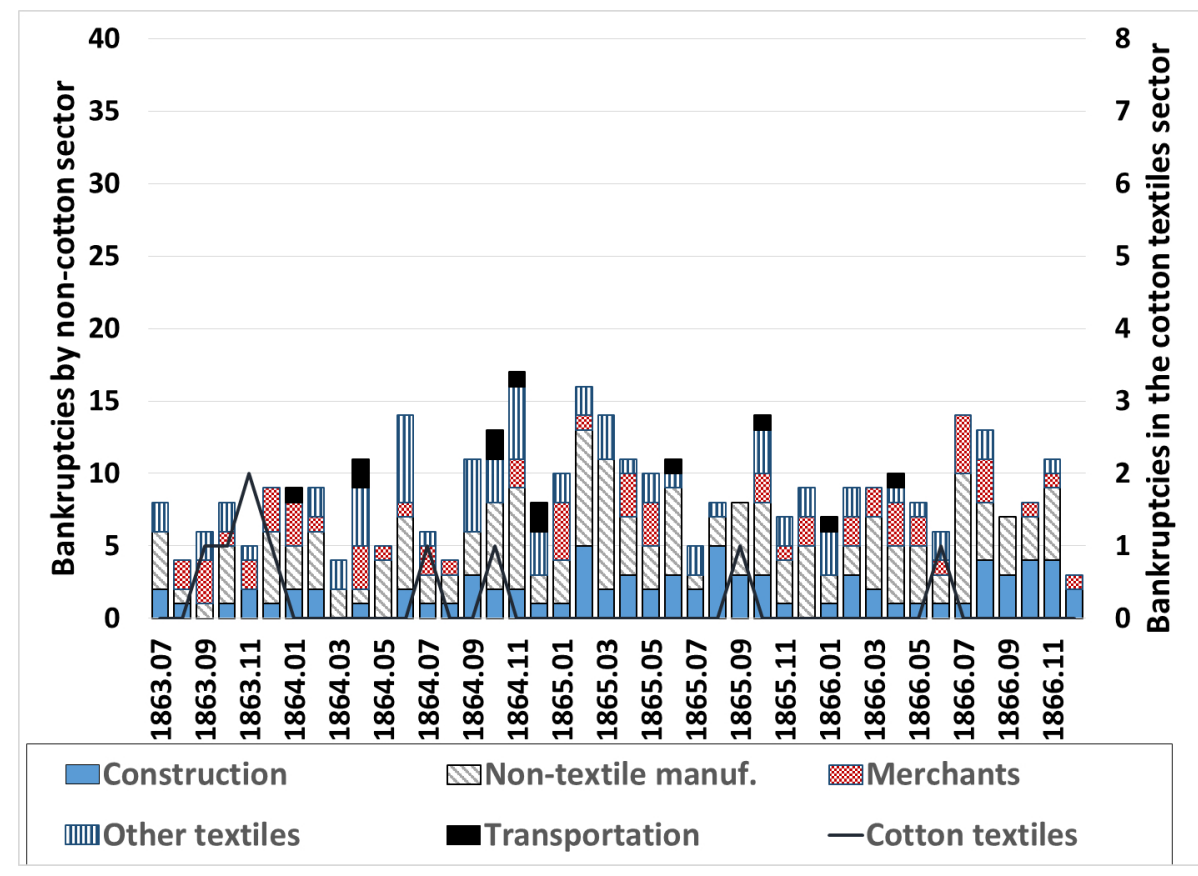

Bankruptcy data were collected from the London Gazette. The bar chart (left-hand axis) describes bankruptcies in a number of industrial sectors related to cotton textiles. Solid line (right-hand axis) describes the number of bankruptcies in the cotton textile sector. The wool textile towns included in this chart are Bradford, Dewsbury, Halifax, Huddersfield, Leeds and Wakefield. 
Figure 14: Bankruptcies outside of the cotton and wool districts

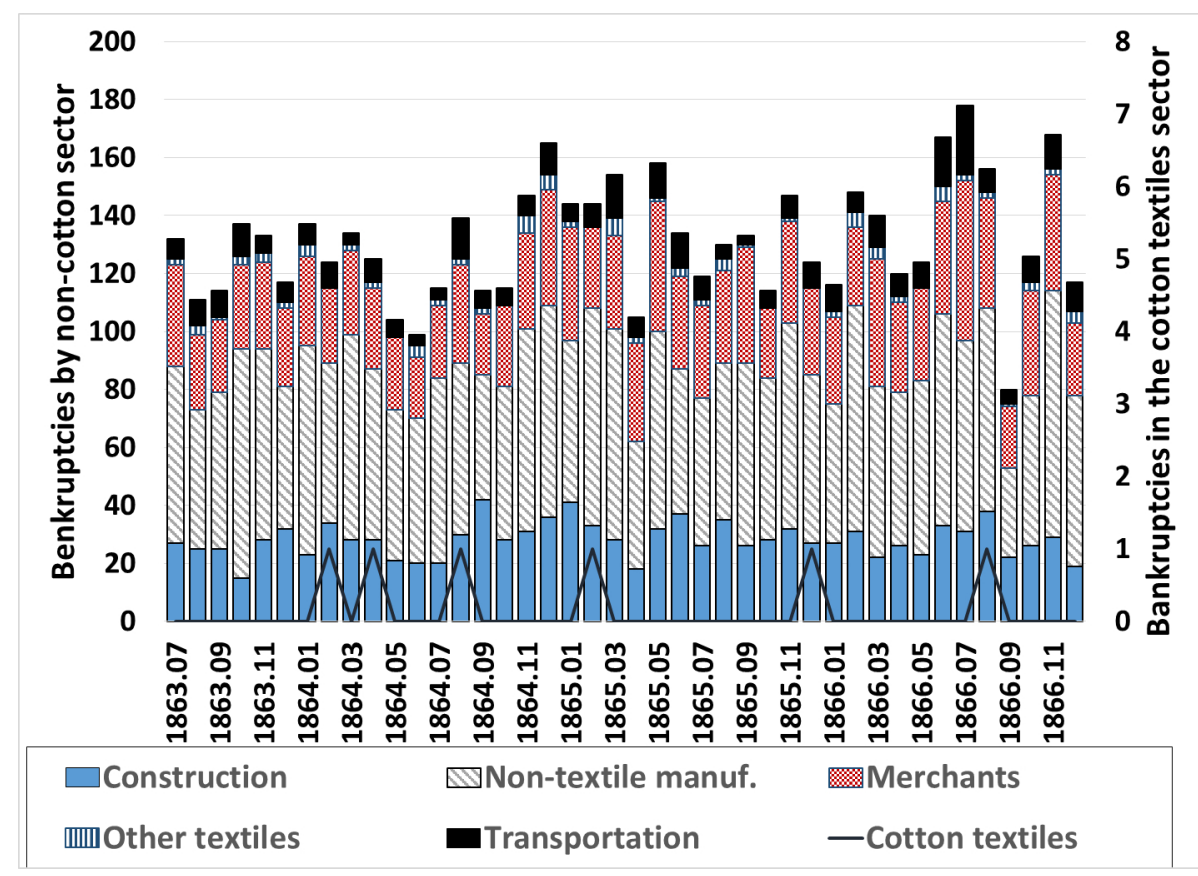

Bankruptcy data were collected from the London Gazette. The bar chart (left-hand axis) describes bankruptcies in a number of industrial sectors related to cotton textiles. Solid line (right-hand axis) describes the number of bankruptcies in the cotton textile sector. The chart includes all of England outside of Lancashire, Cheshire and Yorkshire counties.

Next, I conduct several robustness exercises that look at how my results are affected by some of the decisions made when constructing the data and the empirical exercise. This is done in Table 16. The first column presents results in which I construct the key explanatory variable using a three month window rather than the one-month window used in the main results. The new three month window is centered on the one-month window used in the main text. Thus, for the panic in October, 1864, I look at effects in October, November, and December of 1864. In the second column, I include London, which was excluded from the results presented in the main text for reasons described in the Bankruptcy Data Appendix. In the third column, I assess the impact of my choice to include only towns with more than 30 bankruptcies during the period from mid-1863 through 1866. This column presents results where instead I also include smaller towns with between 25 and 30 bankruptcies. The fourth column addresses the fact that the bankruptcy data include both workers and business owners. This is done by dropping bankruptcies with occupations that include a term that clearly indicates that the bankruptcy is by a worker rather than a business owner. These terms are "Assistant", "Journeyman", "Servant", "Labourer", "Foreman", 
"Manager", "Machinist", "Engineer" (which at this time often means someone who operates an engine), and "Clerk." The fifth column considers the impact of my decision to use only data starting in July, 1863, to generate the results presented in the main text. To do this, this column adds in the data for the first half of 1863. Finally, the sixth column addresses the fact that, for manufacturing industries, the bankruptcy data pool together manufacturers and dealers. I have gone back and reviewed all of the occupations in a set of manufacturing industries in order to separate dealers from manufacturers. Column 6 presents results for these manufacturing industries where all dealers have been dropped from the analysis data. Overall, we can see that they key results presented in the main text - particularly the increase in bankruptcies in Metal \& Machine industries in the cotton textile towns following months of panic in the cotton market - are robust to each of these alternative approaches.

Table 16: Robustness exercises for the bankruptcy results

\begin{tabular}{|c|c|c|c|c|c|c|}
\hline $\begin{array}{l}\text { All } \\
\text { non-cotton }\end{array}$ & $\begin{array}{c}\text { With } \\
3 \text { month } \\
\text { window } \\
0.296^{* *} \\
(0.117)\end{array}$ & $\begin{array}{l}\text { With } \\
\text { London } \\
0.478^{* * *} \\
(0.160)\end{array}$ & $\begin{array}{c}\text { With } \\
\text { smaller } \\
\text { towns } \\
0.473^{* * *} \\
(0.149)\end{array}$ & $\begin{array}{c}\text { Dropping } \\
\text { worker } \\
\text { bankruptcies } \\
0.442^{* *} \\
(0.182)\end{array}$ & $\begin{array}{c}\text { Using } \\
\text { all } 1863 \\
\text { data } \\
0.451^{* * *} \\
(0.157)\end{array}$ & $\begin{array}{c}\text { Makers } \\
\text { only }\end{array}$ \\
\hline Agriculture & $\begin{array}{c}-0.0124 \\
(0.697)\end{array}$ & $\begin{array}{c}0.649 \\
(0.865)\end{array}$ & $\begin{array}{c}0.588 \\
(0.840)\end{array}$ & $\begin{array}{c}0.413 \\
(0.876)\end{array}$ & $\begin{array}{c}0.367 \\
(0.877)\end{array}$ & \\
\hline $\begin{array}{l}\text { Chemicals } \\
\& \text { oils }\end{array}$ & $\begin{array}{c}0.454 \\
(0.512)\end{array}$ & $\begin{array}{c}0.473 \\
(0.491)\end{array}$ & $\begin{array}{c}0.494 \\
(0.490)\end{array}$ & $\begin{array}{l}-0.0815 \\
(0.664)\end{array}$ & $\begin{array}{c}0.174 \\
(0.549)\end{array}$ & $\begin{array}{c}1.466 \\
(1.534)\end{array}$ \\
\hline Construction & $\begin{array}{l}0.390^{*} \\
(0.208)\end{array}$ & $\begin{array}{c}0.392 \\
(0.434)\end{array}$ & $\begin{array}{c}0.506 \\
(0.412)\end{array}$ & $\begin{array}{c}0.213 \\
(0.444)\end{array}$ & $\begin{array}{c}0.148 \\
(0.452)\end{array}$ & \\
\hline $\begin{array}{l}\text { Clothing } \\
\text { \& shoes }\end{array}$ & $\begin{array}{c}-0.0402 \\
(0.412)\end{array}$ & $\begin{array}{c}0.707 \\
(0.640)\end{array}$ & $\begin{array}{c}0.672 \\
(0.621)\end{array}$ & $\begin{array}{c}0.712 \\
(0.656)\end{array}$ & $\begin{array}{c}0.732 \\
(0.659)\end{array}$ & $\begin{array}{c}0.584 \\
(0.610)\end{array}$ \\
\hline Drinks & $\begin{array}{c}0.204 \\
(0.275)\end{array}$ & $\begin{array}{l}-0.175 \\
(0.585)\end{array}$ & $\begin{array}{l}-0.232 \\
(0.572)\end{array}$ & $\begin{array}{c}0.301 \\
(0.621)\end{array}$ & $\begin{array}{c}0.154 \\
(0.634)\end{array}$ & \\
\hline $\begin{array}{l}\text { Food } \\
\text { processing }\end{array}$ & $\begin{array}{c}-0.0448 \\
(0.229)\end{array}$ & $\begin{array}{l}-0.517 \\
(0.611)\end{array}$ & $\begin{array}{l}-0.540 \\
(0.593)\end{array}$ & $\begin{array}{l}-0.490 \\
(0.635)\end{array}$ & $\begin{array}{c}-0.531 \\
(0.614)\end{array}$ & \\
\hline $\begin{array}{l}\text { General } \\
\text { services }\end{array}$ & $\begin{array}{c}0.454 \\
(0.580)\end{array}$ & $\begin{array}{c}0.376 \\
(0.535)\end{array}$ & $\begin{array}{c}0.315 \\
(0.517)\end{array}$ & $\begin{array}{c}0.345 \\
(0.565)\end{array}$ & $\begin{array}{c}0.292 \\
(0.539)\end{array}$ & \\
\hline $\begin{array}{l}\text { Instruments } \\
\& \text { jewelry }\end{array}$ & $\begin{array}{c}0.257 \\
(0.598)\end{array}$ & $\begin{array}{c}0.386 \\
(0.662)\end{array}$ & $\begin{array}{c}0.396 \\
(0.662)\end{array}$ & $\begin{array}{c}0.583 \\
(0.732)\end{array}$ & $\begin{array}{c}0.648 \\
(0.753)\end{array}$ & $\begin{array}{c}-12.37^{* * *} \\
(0.566)\end{array}$ \\
\hline
\end{tabular}


Table 17: Robustness exercises for the bankruptcy results (continued)

\begin{tabular}{|c|c|c|c|c|c|c|}
\hline & $\begin{array}{l}\text { With } \\
3 \text { month }\end{array}$ & $\begin{array}{l}\text { With } \\
\text { London }\end{array}$ & $\begin{array}{l}\text { With } \\
\text { smaller }\end{array}$ & $\begin{array}{l}\text { Dropping } \\
\text { worker }\end{array}$ & $\begin{array}{l}\text { Using } \\
\text { all } 1863\end{array}$ & $\begin{array}{l}\text { Makers } \\
\text { only }\end{array}$ \\
\hline $\begin{array}{l}\text { Leather, } \\
\text { hair goods }\end{array}$ & $\begin{array}{l}0.928^{*} \\
(0.514)\end{array}$ & $\begin{array}{c}0.894 \\
(0.634)\end{array}$ & $\begin{array}{c}0.738 \\
(0.634)\end{array}$ & $\begin{array}{c}0.597 \\
(0.683)\end{array}$ & $\begin{array}{c}0.701 \\
(0.688)\end{array}$ & $\begin{array}{c}0.726 \\
(0.732)\end{array}$ \\
\hline $\begin{array}{l}\text { Merchants } \\
\text { agents, etc. }\end{array}$ & $\begin{array}{c}0.659^{* * *} \\
(0.162)\end{array}$ & $\begin{array}{c}0.587^{* * *} \\
(0.170)\end{array}$ & $\begin{array}{c}0.572^{* * *} \\
(0.179)\end{array}$ & $\begin{array}{c}0.628^{* *} \\
(0.315)\end{array}$ & $\begin{array}{c}0.593^{* *} \\
(0.299)\end{array}$ & \\
\hline $\begin{array}{l}\text { Metal \& } \\
\text { machinery }\end{array}$ & $\begin{array}{l}0.408^{*} \\
(0.217)\end{array}$ & $\begin{array}{c}1.283^{* * *} \\
(0.288)\end{array}$ & $\begin{array}{c}1.202^{* * *} \\
(0.307)\end{array}$ & $\begin{array}{c}1.189^{* * *} \\
(0.372)\end{array}$ & $\begin{array}{c}1.358^{* * *} \\
(0.338)\end{array}$ & $\begin{array}{c}1.625^{* * *} \\
(0.353)\end{array}$ \\
\hline $\begin{array}{l}\text { Mining } \\
\text { related }\end{array}$ & $\begin{array}{c}0.935 \\
(0.641)\end{array}$ & $\begin{array}{c}-14.78^{* * *} \\
(0.473)\end{array}$ & $\begin{array}{c}-14.75^{* * *} \\
(0.448)\end{array}$ & $\begin{array}{c}-15.31^{* * *} \\
(0.526)\end{array}$ & $\begin{array}{c}-15.09^{* * *} \\
(0.524)\end{array}$ & \\
\hline $\begin{array}{l}\text { Non-cotton } \\
\text { textiles }\end{array}$ & $\begin{array}{c}0.815^{* *} \\
(0.372)\end{array}$ & $\begin{array}{c}0.283 \\
(0.586)\end{array}$ & $\begin{array}{l}0.290 \\
(0.587)\end{array}$ & $\begin{array}{c}0.773 \\
(0.610)\end{array}$ & $\begin{array}{c}0.676 \\
(0.687)\end{array}$ & $\begin{array}{l}1.253 \\
(0.805)\end{array}$ \\
\hline $\begin{array}{l}\text { Paper \& } \\
\text { publishing }\end{array}$ & $\begin{array}{l}-0.191 \\
(0.675)\end{array}$ & $\begin{array}{l}1.083^{*} \\
(0.623)\end{array}$ & $\begin{array}{l}1.099^{*} \\
(0.622)\end{array}$ & $\begin{array}{c}0.910 \\
(0.699)\end{array}$ & $\begin{array}{c}0.981 \\
(0.679)\end{array}$ & \\
\hline Professionals & $\begin{array}{c}0.634 \\
(0.401)\end{array}$ & $\begin{array}{c}-13.16^{* * *} \\
(0.715)\end{array}$ & $\begin{array}{c}-13.40^{* * *} \\
(0.674)\end{array}$ & $\begin{array}{c}-13.69^{* * *} \\
(0.871)\end{array}$ & $\begin{array}{c}-12.58^{* * *} \\
(0.844)\end{array}$ & \\
\hline $\begin{array}{l}\text { Shopkeepers, } \\
\text { salesmen, etc }\end{array}$ & $\begin{array}{c}0.116 \\
(0.198)\end{array}$ & $\begin{array}{c}0.370 \\
(0.378)\end{array}$ & $\begin{array}{c}0.432 \\
(0.373)\end{array}$ & $\begin{array}{c}0.420 \\
(0.421)\end{array}$ & $\begin{array}{c}0.352 \\
(0.409)\end{array}$ & \\
\hline $\begin{array}{l}\text { Textile } \\
\text { finish, etc. }\end{array}$ & $\begin{array}{l}0.789^{*} \\
(0.432)\end{array}$ & $\begin{array}{c}0.830 \\
(0.736)\end{array}$ & $\begin{array}{c}0.924 \\
(0.710)\end{array}$ & $\begin{array}{l}1.148 \\
(0.907)\end{array}$ & $\begin{array}{c}0.997 \\
(0.843)\end{array}$ & $\begin{array}{c}0.347 \\
(1.166)\end{array}$ \\
\hline Transport & $\begin{array}{c}0.527 \\
(0.641)\end{array}$ & $\begin{array}{l}1.676 \\
(1.024)\end{array}$ & $\begin{array}{l}1.691^{*} \\
(1.023)\end{array}$ & $\begin{array}{l}1.378 \\
(1.082)\end{array}$ & $\begin{array}{c}1.192 \\
(0.888)\end{array}$ & \\
\hline $\begin{array}{l}\text { Wood \& } \\
\text { furniture }\end{array}$ & $\begin{array}{l}0.0124 \\
(0.369)\end{array}$ & $\begin{array}{l}-0.371 \\
(0.429)\end{array}$ & $\begin{array}{l}-0.386 \\
(0.451)\end{array}$ & $\begin{array}{l}-0.341 \\
(0.462)\end{array}$ & $\begin{array}{l}-0.291 \\
(0.465)\end{array}$ & $\begin{array}{c}0.630 \\
(0.588)\end{array}$ \\
\hline
\end{tabular}

\section{A.5 Additional results using the city-industry data}

This section presents some additional results calculated using the city-industry database. I begin with a robustness exercise related to the results presented in the main text. Next, I offer some additional results obtained using more disaggregated occupation/industry categories.

One feature of the city-industry database, discussed in the online appendix, is that it is necessary to adjust the 1871 data for the number of workers under 20. This is necessary because the data for 1851 and 1861 report employment divided into workers over 19 and 
workers under 20, and the data for 1881-1891 report only total employment, while in 1871 only employment for workers over 20 is reported 40 Because workers under 20 make up an substantial portion of the labor force, it is important to adjust the 1871 data in order to obtain a consistent series. This is done using the national data for 1871, which reports employment by industry divided into workers over 19 and workers under 20. This is used to calculate a share of workers in each industry that were under 20. This share is then applied to adjust employment in each city industry, under the assumption that the share of workers under 20 in any particular industry does not vary too much across cities.

Because 1871 is an important year in the analysis, we may be worried that this adjustment is influencing the results. One way to check this is to use only the data for workers over 19, which is available on a consistent bases for 1851-1871 without the need for adjustment. Using these data, I obtain the results shown in Table 18.

\footnotetext{
${ }^{40}$ An exception is London, where data are reported only for all workers in 1871.
} 
Table 18: Impact on employment for workers over 20 in cotton towns, 1851-1871

\begin{tabular}{|c|c|c|c|c|}
\hline \multirow{2}{*}{ Industry } & \multicolumn{2}{|c|}{ All towns } & \multicolumn{2}{|c|}{ Only textile towns } \\
\hline & Coef & SE & Coef & SE \\
\hline Silk textiles & -0.6027 & $(0.4078)$ & -0.0759 & $(0.4423)$ \\
\hline Tobacco & -0.5310 ** & $(0.2331)$ & -0.1542 & $(0.2722)$ \\
\hline Metal \& machinery & -0.2844 *** & $(0.1072)$ & $-0.5851^{* * *}$ & $(0.1777)$ \\
\hline Earthenware, bricks, etc. & -0.1573 & $(0.1507)$ & -0.2625 & $(0.1760)$ \\
\hline Textile finishing, etc. & -0.0956 & $(0.1736)$ & 0.3121 & $(0.2221)$ \\
\hline Mining related & -0.0896 & $(0.1036)$ & -0.1009 & $(0.1169)$ \\
\hline Wool textiles & -0.0819 & $(0.0948)$ & $-0.3661^{* * *}$ & $(0.1269)$ \\
\hline Professionals & -0.0814 & $(0.0751)$ & $-0.2355^{* *}$ & $(0.0994)$ \\
\hline Paper \& publishing & -0.0758 * & $(0.0453)$ & -0.1010 & $(0.0795)$ \\
\hline Construction & -0.0549 & $(0.0801)$ & -0.2259 * & $(0.1160)$ \\
\hline Vehicles & -0.0451 & (0.1261) & -0.1353 & $(0.1440)$ \\
\hline Food processing & -0.0226 & $(0.0326)$ & -0.0381 & $(0.0608)$ \\
\hline Drinks & 0.0272 & $(0.0352)$ & -0.0604 & $(0.0528)$ \\
\hline Chemicals \& drugs & 0.0362 & $(0.1417)$ & $-0.3537 *$ & $(0.2004)$ \\
\hline Wood \& furniture & 0.0389 & $(0.0512)$ & -0.1132 & $(0.0692)$ \\
\hline Cotton textiles & 0.0400 & $(0.1876)$ & 0.3175 & $(0.2707)$ \\
\hline Drinks & 0.1197 & $(0.1379)$ & -0.0394 & $(0.1591)$ \\
\hline Instruments \& jewelry & 0.1360 & $(0.0868)$ & 0.2046 & $(0.2848)$ \\
\hline Messengers, warehousing, etc. & 0.1431 & $(0.2491)$ & -0.2853 & $(0.2759)$ \\
\hline Water \& gas service & 0.1772 & $(0.1090)$ & 0.2520 * & $(0.1494)$ \\
\hline Road transport & 0.1785 & $(0.2917)$ & 0.1937 & $(0.3081)$ \\
\hline Sea \& canal transport & 0.1802 & $(0.1845)$ & 0.2496 & $(0.2472)$ \\
\hline Shopkeepers \& salesmen & $0.2146^{* * *}$ & $(0.0699)$ & 0.0607 & $(0.0963)$ \\
\hline Merchant, agents, etc. & $0.2575^{* * *}$ & $(0.0969)$ & $0.3148^{* \star *}$ & $(0.1150)$ \\
\hline Leather \& hair goods & 0.2659 *** & $(0.0757)$ & 0.2691 & $(0.2082)$ \\
\hline Shipbuilding & 0.3205 & $(0.3203)$ & 0.4583 & $(0.4553)$ \\
\hline Oils \& soaps manuf. & $0.3300 * *$ & $(0.1665)$ & -0.0282 & $(0.3126)$ \\
\hline Railway transport & $0.3933^{* * \star}$ & $(0.1143)$ & 0.1329 & $(0.1240)$ \\
\hline Flax, linen, fustian & 0.6661 ** & $(0.2889)$ & -0.3865 & $(0.3847)$ \\
\hline
\end{tabular}

${ }^{* * *} \mathrm{p}<0.01,{ }^{* *} \mathrm{p}<0.05,{ }^{*} \mathrm{p}<0.1$. Table displays $a^{i}$ coefficients and standard errors based on the regression specification in Equation3. The data cover 1851-1871 and include only workers over 19 years of age. The first set of results use data on 71 towns with 2096 city-industries and 4161 observations. The second set of results use data on 18 textile towns with 534 city-industries and 1064 observations. In both sets, there are 8 cotton textile towns. The regressions include a full set of city-industry and industry-year effects. Standard errors, shown in parenthesis, are clustered by city-industry, city-year, and industry-year. The omitted industry is "General services."

To gain additional insight into the results reported in the main text, we can apply a similar approach to the same data, but with a more disaggregated set of occupation/industry definitions. These disaggregated data include 152 industry categories and cover the 25 analysis towns over the period 1851-1891. I use exactly the same procedure as was used to 
generate the results shown in Table 11. This procedure generates 151 coefficients describing how each industry fared in the cotton towns, relative to comparator towns, in the post-shock period. For brevity, I present only the 20 most negatively and most positively affected industries (based on the estimated coefficient). The first set of results, reported in Table 19 . include all towns. The second set of results, reported in Table 20 include only the textile towns.

In both sets of results, we can see that there are a set of negatively affected metal \& machinery categories. This includes pin and needle makers, which would have supplied cards the the cotton textile industry, an important input. Engine and machine manufacturers, a key capital input supplier, also show significant negative impacts in both sets of results. Textile categories, such as worsted textile manufacturing, wool textile manufacturing, and silk textile manufacturing, show consistent negative effects. Finally, there are a number of construction related classes, such as bricklayers and stone workers, that show consistent negative results.

Table 19: Long-run impact on disaggregated industry categories (all towns)

\begin{tabular}{|c|c|c|c|c|c|}
\hline \multicolumn{3}{|c|}{ Twenty most negatively affected } & \multicolumn{3}{|c|}{ Twenty most positively affected } \\
\hline Industry & Coefficient & $\underline{\mathrm{SE}}$ & Industry & Coefficient & $\underline{\mathrm{SE}}$ \\
\hline $\overrightarrow{\text { Pin, needle manuf. }}$ & -2.0028 & $(0 . \overline{2182})$ & $\overrightarrow{\text { Carpet, rug manuf. }}$ & 0.4351 & $(0 . \overline{1770})$ \\
\hline Wool staplers & -1.3299 & $(0.3342)$ & Auctioneers & 0.4411 & $(0.0977)$ \\
\hline Worsted textiles & -1.2688 & $(0.4911)$ & Soap manuf. & 0.4574 & $(0.3993)$ \\
\hline Silk textiles & -1.0886 & $(0.2715)$ & Corn miller & 0.4659 & $(0.2129)$ \\
\hline Misc. stone workers & -0.9116 & $(0.3486)$ & Game, sports equip. & 0.4701 & $(0.3014)$ \\
\hline Wool textiles & -0.7445 & $(0.3275)$ & Arms & 0.5169 & $(0.4076)$ \\
\hline Patternmakers, draughtsman & -0.6848 & $(0.3312)$ & Road construction & 0.5417 & $(0.2943)$ \\
\hline Copper workers & -0.6507 & $(0.2245)$ & Zinc workers & 0.5588 & $(0.2956)$ \\
\hline Button manuf. & -0.5335 & $(0.2601)$ & Hosiery manuf. & 0.5861 & $(0.4818)$ \\
\hline General shopkeepers & -0.5221 & $(0.1829)$ & Seamstress \& shirtmakers & 0.5958 & $(0.2040)$ \\
\hline Laundry & -0.4294 & $(0.1015)$ & Misc. cotton, flax workers & 0.6179 & $(0.5587)$ \\
\hline Engine and machine manuf. & -0.4170 & $(0.1178)$ & Hemp, jute, etc. & 0.6406 & $(0.2515)$ \\
\hline Bricklayers & -0.3981 & $(0.1502)$ & rubber_oils_etc & 0.6418 & $(0.2650)$ \\
\hline Artificial flowers & -0.3666 & $(0.2006)$ & Gold \& silver workers & 0.6688 & $(0.1892)$ \\
\hline Corn, vegitable retailer & -0.3586 & $(0.2683)$ & Cotton finishing & 0.7444 & $(0.4313)$ \\
\hline Cheesemonger & -0.3567 & $(0.2375)$ & Anchor and chain manuf. & 0.8322 & $(0.1812)$ \\
\hline Rag gatherer & -0.3560 & $(0.1676)$ & Glovers & 0.8614 & $(0.3921)$ \\
\hline Iron manufacture & -0.3305 & $(0.2130)$ & Instruments & 0.8687 & $(0.3235)$ \\
\hline Salt maker & -0.3302 & $(0.2750)$ & Paper stainer & 1.0409 & $(0.4733)$ \\
\hline Engineers & -0.2999 & $(0.1570)$ & Thread manuf & 2.0881 & $(0.6818)$ \\
\hline
\end{tabular}

${ }^{* * *} \mathrm{p}<0.01,{ }^{* *} \mathrm{p}<0.05,{ }^{*} \mathrm{p}<0.1$. Table displays $b^{i}$ coefficients and standard errors based on the regression specification in Equation 4. The data cover 1851-1891. The first set of results use data on 25 towns with 6 cotton textile towns. The regressions include a full set of city-industry and industry-year effects. Standard errors, shown in parenthesis, are clustered by city-industry, city-year, and industry-year. The omitted industry is "Domestic service." 
Table 20: Long-run impact on disaggregated industry categories (textile towns only)

\begin{tabular}{|c|c|c|c|c|c|}
\hline \multicolumn{3}{|c|}{ Twenty most negatively affected } & \multicolumn{3}{|c|}{ Twenty most positively affected } \\
\hline Industry & $\underline{\text { Coefficient }}$ & $\underline{\mathrm{SE}}$ & Industry & Coefficient & $\underline{\mathrm{SE}}$ \\
\hline Pin, needle manuf. & -2.426 & $(0.1951)$ & Wood \& bark goods & 0.318 & $(0.3173)$ \\
\hline Worsted textiles & -1.672 & $(0.7409)$ & Instruments & 0.322 & $(0.3318)$ \\
\hline Arms & -1.655 & $(0.8353)$ & Seamstress \& shirtmakers & 0.369 & $(0.2172)$ \\
\hline Wool staplers & -1.277 & $(0.4828)$ & Salesmen & 0.372 & $(0.2971)$ \\
\hline Copper workers & -1.187 & $(0.3548)$ & Game, sports equip. & 0.390 & $(0.3660)$ \\
\hline Misc. stone workers & -1.091 & $(0.6031)$ & Cotton finishing & 0.413 & $(0.3995)$ \\
\hline Wool textiles & -1.065 & $(0.4309)$ & Auctioneers & 0.439 & $(0.1643)$ \\
\hline Silk textiles & -1.013 & $(0.3951)$ & Hemp, jute, etc. & 0.443 & $(0.2856)$ \\
\hline Textile finishing, etc & -0.820 & $(0.4990)$ & Road construction & 0.468 & $(0.3711)$ \\
\hline Artificial flowers & -0.756 & $(0.3074)$ & Gold \& silver workers & 0.474 & $(0.2126)$ \\
\hline Bricklayers & -0.728 & $(0.2947)$ & Misc. paper workers & 0.535 & $(0.2230)$ \\
\hline Earthenware manuf. & -0.714 & $(0.5516)$ & Zinc workers & 0.549 & $(0.3123)$ \\
\hline Nail manuf. & -0.690 & $(0.1037)$ & Hatters & 0.555 & $(0.3578)$ \\
\hline Glass manuf. & -0.688 & $(0.3437)$ & Misc. earthenware & 0.581 & $(0.2827)$ \\
\hline Button manuf. & -0.676 & $(0.4643)$ & Merchants & 0.627 & $(0.3840)$ \\
\hline Cheesemonger & -0.657 & $(0.2427)$ & Glovers & 0.681 & $(0.4082)$ \\
\hline Fur goods & -0.657 & $(0.3754)$ & Oil and colourman & 0.800 & $(0.3780)$ \\
\hline Engine and machine manuf. & -0.655 & $(0.1379)$ & Anchor and chain manuf. & 0.833 & $(0.2951)$ \\
\hline Railway construction & -0.612 & $(0.2935)$ & Misc. jewelry & 1.036 & $(0.5381)$ \\
\hline Laundry & -0.522 & $(0.1292)$ & Thread manuf. & 2.861 & $(0.8562)$ \\
\hline
\end{tabular}

${ }^{* * *} \mathrm{p}<0.01,{ }^{* *} \mathrm{p}<0.05,{ }^{*} \mathrm{p}<0.1$. Table displays $b^{i}$ coefficients and standard errors based on the regression specification in Equation 4. The data cover 1851-1891. The first set of results use data on 25 towns with 6 cotton textile towns. The regressions include a full set of city-industry and industry-year effects. Standard errors, shown in parenthesis, are clustered by city-industry, city-year, and industry-year. The omitted industry is "Domestic service." 